\title{
Global tropospheric ozone variations from 2003 to 2011 as seen by SCIAMACHY
}

\author{
F. Ebojie ${ }^{1}$, J. P. Burrows ${ }^{1}$, C. Gebhardt ${ }^{1}$, A. Ladstätter-Weißenmayer ${ }^{1}$, C. von Savigny ${ }^{2}$, A. Rozanov ${ }^{1}$, M. Weber ${ }^{1}$, and \\ H. Bovensmann ${ }^{1}$ \\ ${ }^{1}$ Institute of Environmental Physics (IUP), University of Bremen, P.O. Box 330440, 28334 Bremen, Germany \\ ${ }^{2}$ Institute of Physics, Ernst-Moritz-Arndt University of Greifswald, Felix-Hausdorff-Str. 6, 17489 Greifswald, Germany \\ Correspondence to: F. Ebojie (felix@iup.physik.uni-bremen.de)
}

Received: 8 July 2015 - Published in Atmos. Chem. Phys. Discuss.: 7 September 2015

Revised: 16 December 2015 - Accepted: 21 December 2015 - Published: 19 January 2016

\begin{abstract}
An analysis of the tropospheric ozone $\left(\mathrm{O}_{3}\right)$ columns (TOCs) derived from SCIAMACHY limb-nadirmatching (LNM) observations during the period 2003-2011, focusing on global variations in TOC, is described. The changes are derived using a multivariate linear regression model. TOC shows changes of $-0.2 \pm 0.4,0.3 \pm 0.4,0.1 \pm 0.5$ and $0.1 \pm 0.2 \% \mathrm{yr}^{-1}$, which are not statistically significant at the $2 \sigma$ level in the latitude bands $30-50^{\circ} \mathrm{N}, 20^{\circ} \mathrm{S}-0,0$ $20^{\circ} \mathrm{N}$ and $50-30^{\circ} \mathrm{S}$, respectively. Tropospheric $\mathrm{O}_{3}$ shows statistically significant increases over some regions of South Asia $\left(1-3 \% \mathrm{yr}^{-1}\right)$, the South American continent (up to $2 \% \mathrm{yr}^{-1}$ ), Alaska (up to $2 \% \mathrm{yr}^{-1}$ ) and around Congo in Africa (up to $2 \% \mathrm{yr}^{-1}$ ). Significant increase in TOC is determined off the continents including Australia (up to $2 \% \mathrm{yr}^{-1}$ ), Eurasia (1-3\% $\mathrm{yr}^{-1}$ ) and South America (up to $3 \% \mathrm{yr}^{-1}$ ). Significant decrease in TOC (up to $-3 \% \mathrm{yr}^{-1}$ ) is observed over some regions of the continents of North America, Europe and South America. Over the oceanic regions including the Pacific, North Atlantic and Indian oceans, significant decreases in TOC $\left(-1\right.$ to $\left.-3 \% \mathrm{yr}^{-1}\right)$ were observed. In addition, the response of the El Niño-Southern Oscillation (ENSO) and quasi-biennial oscillation (QBO) to changes in TOC for the period 2003-2011 was investigated. The result shows extensive regions, mostly in the tropics and Northern Hemisphere extratropics, of significant ENSO responses to changes in TOC and a significant QBO response to TOC changes over some regions.
\end{abstract}

\section{Introduction}

Tropospheric ozone $\left(\mathrm{O}_{3}\right)$ is a major environmental concern. The amount of tropospheric $\mathrm{O}_{3}$ has been shown to be increasing globally during the 20th century due to enhanced emissions of anthropogenic precursors (Marenco et al., 1994; Shindell et al., 2006). Tropospheric $\mathrm{O}_{3}$ is an important greenhouse gas and a pollutant. It affects air quality and contributes to global warming (e.g. Shindell et al., 2006; Jacob and Winner, 2009). It is responsible for respiratory diseases in humans, leads to premature mortality, and causes damage to crops and ecosystems (e.g. Lippmann, 1991; Jacobson, 2012). Ozone is a strong oxidant and a precursor of hydroxyl $(\mathrm{OH})$ and hydroperoxy $\left(\mathrm{HO}_{2}\right)$ radicals, which drive tropospheric chemistry (Levy, 1971; Logan et al., 1981). Tropospheric $\mathrm{O}_{3}$ has two main sources: photochemical production within the troposphere and transport from the stratosphere. The photochemical source of tropospheric $\mathrm{O}_{3}$ is mainly controlled by emissions of $\mathrm{O}_{3}$ precursors including nitrogen oxides $\left(\mathrm{NO}_{x}\right)$ and volatile organic compounds (VOCs) (Hao and Wang, 1952; Lelieveld and Dentener, 2000). Instantaneous rates of formation of $\mathrm{O}_{3}$ are dependent on the relation between $\mathrm{O}_{3}, \mathrm{NO}_{x}$ and VOC from which two regimes with different $\mathrm{O}_{3}-\mathrm{NO}_{x}-\mathrm{VOC}$ sensitivities can be identified, i.e. a $\mathrm{NO}_{x}$-sensitive regime (limited $\mathrm{NO}_{x}$ and high VOC) and a VOC-sensitive regime (saturated $\mathrm{NO}_{x}$ and low VOC). In the $\mathrm{NO}_{x}$-sensitive regime, $\mathrm{O}_{3}$ concentrations increase with increasing $\mathrm{NO}_{x}$ and exhibit little response to increasing VOC. In the VOC-sensitive regime, $\mathrm{O}_{3}$ concentrations decrease with increasing $\mathrm{NO}_{x}$ and increase with increasing VOC. While the $\mathrm{NO}_{x}$-sensitive regime is associ- 
ated with high $\mathrm{VOC} / \mathrm{NO}_{x}$ ratios, the $\mathrm{VOC}$-sensitive regime is associated with low VOC $/ \mathrm{NO}_{x}$ ratios. The $\mathrm{O}_{3}-\mathrm{NO}_{x}-$ VOC sensitivity varies with location, events and time. The VOC-sensitive chemistry is more likely in urban or pollution source regions, while $\mathrm{NO}_{x}$-sensitive chemistry is more likely downwind (Milford et al., 1989; Duncan et al., 2010). $\mathrm{O}_{3}$ precursors such as $\mathrm{NO}_{x}$ and VOCs are emitted from fossil fuel combustion, power plants, biomass burning, lightning and other combustion sources. They are also emitted from microbes in the soil and from vegetation (Guenther et al., 2000). High amounts of $\mathrm{O}_{3}$ precursors anthropogenically produced can accumulate to a hazardous level during favourable meteorological conditions (Zhang et al., 1998). The reaction of carbon monoxide $(\mathrm{CO})$, VOCs, and methane $\left(\mathrm{CH}_{4}\right)$ with $\mathrm{OH}$ radicals is the main source of peroxy $\left(\mathrm{RO}_{2}, \mathrm{HO}_{2}\right)$ radicals, which facilitate the conversion of nitric oxide (NO) to nitrogen dioxide $\left(\mathrm{NO}_{2}\right)$. Hence, a decrease in the chemical fuels $\left(\mathrm{CO}, \mathrm{VOCs}, \mathrm{CH}_{4}\right)$ may ultimately lead to a decrease in the production of $\mathrm{NO}_{2}$. Increase in tropospheric $\mathrm{NO}_{x}$ concentrations can lead to increases in $\mathrm{O}_{3}$. However, under conditions of high $\mathrm{NO}_{x}$ (reaching levels beyond $10 \mathrm{ppb}$ ), which are found mainly in pollution source regions in some urban centres and around power plants, $\mathrm{O}_{3}$ can be lost or titrated via the reaction $\mathrm{NO}+\mathrm{O}_{3} \rightarrow \mathrm{NO}_{2}+\mathrm{O}_{2}$ (e.g. Sillman et al., 1990; Brasseur et al., 1999). Nevertheless, $\mathrm{O}_{3}$ is reformed downwind in the plume from urban areas (e.g. Crutzen, 1979).

The influx of $\mathrm{O}_{3}$-rich stratospheric air through stratosphere-troposphere exchange (STE) also contributes to tropospheric $\mathrm{O}_{3}$ abundance. $\mathrm{O}_{3}$ is transported from the lower stratosphere into the upper troposphere through tropopause foldings (Danielsen, 1968; Fusco and Logan, 2003) and it is exchanged with the troposphere via diabatic processes and turbulent diffusion (Lamarque and Hess, 1994), mixing processes and convective injection during the breakup of stratospheric filaments (e.g. Appenzeller et al., 1996).

Chemical removal of tropospheric $\mathrm{O}_{3}$ occurs by photolysis and catalytic reactions involving hydrogen and oxides of hydrogen $\left(\mathrm{OH}+\mathrm{HO}_{2}\right)$ as well as halogen and halogen oxides (Finlayson-Pitts et al., 1990; Monks, 2005; Gentner et al., 2014). In addition, $\mathrm{O}_{3}$ oxidizes VOCs with double bonds (e.g. isoprene, methanol, acetone) and is also removed from the troposphere by deposition to the surface. The photolysis of $\mathrm{O}_{3}$ plays a key role in tropospheric chemistry, and it is strongly determined by the stratospheric $\mathrm{O}_{3}$ column. It has been observed that a negative trend in stratospheric $\mathrm{O}_{3}$ enhances the $\mathrm{O}_{3}$ photolysis in the troposphere as a result of increasing UV-B radiation (WMO, 1999). The combination of sources, loss processes and transport within the troposphere determines the amount of $\mathrm{O}_{3}$ at any given time and location within the troposphere, i.e. its spatial and temporal distribution and variability.

The factors contributing to trends in background $\mathrm{O}_{3}$ include changes in emissions of $\mathrm{O}_{3}$ precursors, meteorological variability (changes in temperature and solar radiation), and regional and intercontinental transport of $\mathrm{O}_{3}$ and its precur- sors (Jacob et al., 1999; Liu et al., 2002). Changes in circulation and stratospheric ozone intrusions also play a role (e.g. Dickerson et al., 1995; Cooper and Parrish, 2004). Furthermore, long-range ozone transport within the troposphere is modulated by interannual to decadal climate variability (e.g. Lin et al., 2014; Ziemke et al., 2015).

In the 20th century, the annual mean concentrations of tropospheric $\mathrm{O}_{3}$ at the northern mid and high latitudes were found to have more than doubled due to anthropogenic activities (Marenco et al., 1994; Shindell et al., 2006). Although $\mathrm{O}_{3}$ mitigation efforts in the developed countries have led to a decrease in peak $\mathrm{O}_{3}$ levels in both urban and rural areas and led to negative trends on a regional scale, particularly over Europe and North America in recent years (Naja et al., 2003; Derwent et al., 2003; Cooper et al., 2014; Parrish et al., 2013, 2014), background levels continue to increase in some regions (Oltmans et al., 2006). Furthermore, $\mathrm{O}_{3}$ concentrations over some developed and developing countries are rising due to increased emissions of $\mathrm{NO}_{x}$ and other $\mathrm{O}_{3}$ precursors from anthropogenic activities (e.g. Dentener et al., 2005). As a result of regional and intercontinental transport of $\mathrm{O}_{3}$ (e.g. Fiore et al., 2009; Parrish et al., 1993), increase in $\mathrm{O}_{3}$ is not only limited to local/regional sources, but also to hemispheric-scale sources (TOR-2, 2003). Therefore, reductions in local or national emissions of $\mathrm{O}_{3}$ do not always produce an analogous decrease in atmospheric concentrations.

Trends in tropospheric $\mathrm{O}_{3}$ have been derived from measurements from urban and rural sites (e.g, Oltmans et al., 2006, 2013; Cooper et al., 2012), ozonesondes and commercial aircrafts (e.g. Logan et al., 2012). Ozone trends derived from satellite measurements have been published (e.g. Ziemke et al., 2005; Beig and Singh, 2007). Some of the tropospheric $\mathrm{O}_{3}$ column (TOC) trends based on satellite measurements are derived from different instruments with differing algorithms and sampling characteristics, and this can introduce some uncertainties in the data sets (Beig and Singh, 2007; Doughty et al., 2011). Most of the past tropospheric $\mathrm{O}_{3}$ trend studies focused on regional pollution in the Northern Hemisphere $(\mathrm{NH})$, where $\mathrm{O}_{3}$ precursors are well characterized (e.g. Logan et al., 2012; Parrish et al., 2012). The goal of this study is to determine the global and zonal changes in the tropospheric $\mathrm{O}_{3}$ data product derived from SCIAMACHY limb-nadir-matching (LNM) observations during the period 2003-2011 (Ebojie et al., 2014; Ebojie, 2014). The manuscript is organized as follows: Sect. 2 briefly describes the data and regression model used in this study. Sect. 3 provides results and discussion, and Sect. 4 summarizes principal findings and conclusions.

\section{Data and regression model}

In this work, the TOC time series derived from SCIAMACHY limb and nadir measurements for the period of 2003-2011 using the LNM technique (Ebojie et al., 2014; 
Ebojie, 2014) have been used to investigate their global and zonal linear trends. The LNM technique is a residual approach that subtracts stratospheric $\mathrm{O}_{3}$ columns (SOCs), retrieved from the limb observations, from the total $\mathrm{O}_{3}$ columns (TOZs), derived from the nadir observations. The technique requires accurate knowledge of the SOCs, TOZs, tropopause height, and their associated errors. The SOCs were determined from the stratospheric $\mathrm{O}_{3}$ profiles retrieved in the Hartley and Chappuis bands of $\mathrm{O}_{3}$ from SCIAMACHY limb scattering measurements. The TOZs were also derived from SCIAMACHY measurements, but in this case from the nadir-viewing mode using the weighting function differential optical absorption spectroscopy (WFDOAS) technique in the Huggins band of $\mathrm{O}_{3}$. Since TOCs constitute only about $10 \%$ of the TOZs, small errors associated with clouds might significantly affect the derived TOCs. Therefore, limb scenes that are contaminated with clouds and nadir measurements that have a cloud fraction of more than 0.1 were screened out. The TOCs derived from SCIAMACHY LNM observations were thoroughly validated by comparison with a large suite of correlative TOC data sets derived from balloon-borne platforms and concurrent satellite measurements. The results of this extensive validation are described in Ebojie (2014) and Ebojie et al. (2014). These studies demonstrate the high quality of SCIAMACHY TOC and show no observable drifts in the validation with other tropospheric $\mathrm{O}_{3}$ data sets. However, further improvement for the limb vertical profile may reduce the error in the TOC. The SCIAMACHY TOCs show good agreement with TOCs derived from other satellite instruments, and comparison with co-located ozonesonde measurements shows agreement to within $3 \mathrm{DU}$ (Dobson units) on average (Ebojie et al., 2014; Ebojie, 2014). Detailed discussion of the LNM technique applied to the retrieval of TOC from SCIAMACHY, a sensitivity study and validation of the SCIAMACHY TOC are given in Ebojie (2014) and Ebojie et al. (2014).

The SCIAMACHY tropospheric $\mathrm{O}_{3}$ changes are determined using a multivariate linear regression taking the autocorrelation of consecutive values into account. This helps one to obtain more realistic uncertainties in the TOC trends, thus giving a better understanding of what drives $\mathrm{O}_{3}$ trends and variability. The implemented approach is similar to that used for stratospheric $\mathrm{O}_{3}$ trends and variability by Gebhardt et al. (2014). The regression model is expressed as

$Z_{t}=\mu+\omega t+S_{t}+R(t)+\epsilon(t)$,

where $Z_{t}$ is the monthly mean tropospheric $\mathrm{O}_{3}$ data, $t$ is the month index (1-108), $\mu$ is the intercept, $\epsilon$ is the error term, and $\omega$, which is the gradient or slope, represents the linear trend. $S_{t}$ is the seasonal component including annual, semi-annual and 3- and 4-month harmonic terms as shown in Eq. (2).
$S_{t}=\sum_{i=1}^{4}\left(\beta_{1 i} \sin \left(\frac{2 \pi i t}{12}\right)+\beta_{2 i} \cos \left(\frac{2 \pi i t}{12}\right)\right)$

$\beta_{1 i}$ and $\beta_{2 i}$ are parameters, which are determined to fit the amplitude and phase of the oscillations (e.g. von Clarmann et al., 2010; Eckert et al., 2014). The harmonics (12-, 6-, 4-, 3 -month) are used to represent seasonal changes (Weatherhead et al., 2000). The 12 and 6 months correspond to the annual and semi-annual cycles, respectively. The terms with the 3- and 4-month periods help to improve the fit quality mostly when the cycle shape is not sinusoidal (Stiller et al., 2012). The combination of sine and cosine terms provides a flexible adjustment to any phase of the periodic variation. $R(t)$ represents additional terms including the quasi-biennial oscillation (QBO) and El Niño-Southern Oscillation (ENSO), which can be expressed as

$$
\begin{aligned}
R(t)= & m \mathrm{QBO}_{50}(t)+n \mathrm{QBO}_{70}(t) \\
& +x\left(\mathrm{~N}_{34}(t)+\frac{\mathrm{dN}_{34}(t)}{\mathrm{d} t} \Delta(t)\right) .
\end{aligned}
$$

The first and second terms of Eq. (3) are the QBO terms, while the last term corresponds to the ENSO term. The factors $m, n$ and $x$ represent their fit coefficients. The QBO indices of 50 and 70 denote the pressure level of the proxy (in $\mathrm{hPa}$ ). The solar term is not included in the regression model because the residuals show no evidence of a solar-cycle response. The different contributions to the regression model are described in more detail in Sect. 2.1. The trend uncertainty is $1 \sigma$, which is defined by the covariance matrix of the regression coefficients. The trends and their uncertainties are presented in relative units of $\% \mathrm{yr}^{-1}$, i.e. percent per year relative to the mean value of the underlying time series. The reported changes in TOC are considered statistically significant at the $95 \%$ confidence level if the absolute ratio of the trend to its uncertainty is greater than 2 (Tiao et al., 1990).

\subsection{Quasi-biennial oscillation and El Niño-Southern Oscillation signatures in ozone}

El Niño-Southern Oscillation (ENSO) and quasi-biennial oscillation (QBO) influence tropospheric $\mathrm{O}_{3}$ through modulation of the stratospheric circulation (e.g. Simpson et al., 2011; Baldwin et al., 2001), stratospheric $\mathrm{O}_{3}$ (e.g. Oman et al., 2013), and STE $\mathrm{O}_{3}$ influx (e.g. Zeng and Pyle, 2005). QBO is characterized by alternating easterly and westerly wind regimes within a variable period of $2-3$ years in the tropics (Pascoe et al., 1948). The QBO directly modulates tropical upwelling through the thermal wind balance. Although the QBO is a tropical phenomenon, it influences the entire stratospheric flow by modulating the effects of extratropical waves. It regulates the upwelling branch of the Brewer-Dobson circulation (BDC) and leads to variation 
in the $\mathrm{O}_{3}$ volume mixing ratio (VMR) mostly at the altitudes of a steep $\mathrm{O}_{3}$ VMR gradient, which is found below and above the maximum in the vertical $\mathrm{O}_{3}$ VMR profiles (Butchart et al., 2003). QBO has been identified as affecting the troposphere indirectly through its effect on the polar vortex (e.g. Holton and Tan, 1980). It directly affects the tropical and extratropical troposphere through convective anomalies (Haigh et al., 2005; Neu et al., 2014). Evidence of a QBO signal in the tropical troposphere $\mathrm{O}_{3}$ has been recorded from satellite and ozonesonde measurements (e.g. Chandra et al., 2002; Lee et al., 2010). QBO can also affect the troposphere through tropospheric eddies even in the absence of an anomalous polar vortex or tropical convection (e.g. Garfinkel and Hartmann, 2011). A downward propagating $\mathrm{QBO} \mathrm{O}_{3}$ signal has been found to extend to the mid-troposphere where the phase analysis of the temperature anomalies implies that the driving force is a zonal mean overturning circulation associated with thermal wind adjustment (Lee et al., 2010). In the present study, the 50 and $70 \mathrm{hPa}$ Singapore $\left(1^{\circ} \mathrm{N}, 140^{\circ} \mathrm{E}\right)$ winds (http://www.geo.fu-berlin. de/en/met/ag/strat/produkte/qbo/, last access: 28 April 2015) are used as fit proxies. They are smoothed by a 4-month running mean and used globally in the form of Eq. (4).

$\mathrm{QBO}(t)=m \mathrm{QBO}_{50}(t)+n \mathrm{QBO}_{70}(t)$

Another dominant driver of interannual tropospheric variability is ENSO with a varying period of 2-7years, and which maximizes around late boreal autumn to late winter (Bjerknes, 1966). The response of tropospheric $\mathrm{O}_{3}$ to ENSO has been demonstrated in earlier studies (Chandra et al., 1998; Ladstätter-Weißenmayer et al., 1999; Zeng and Pyle, 2005; Valks et al., 2014; Ziemke et al., 2014; ColdeweyEgbers et al., 2014). Response to circulation and convective changes during El Niño leads to a decrease in TOC in the central and eastern Pacific and an increase in the western Pacific/Indonesia (Fujiwara et al., 1999; Thompson et al., 2001; Valks et al., 2014; Ziemke et al., 2014). Statistically significant signals consistent with anomalous vertical motions during ENSO have been observed from tropospheric $\mathrm{O}_{3}$ profiles associated with the Southern Oscillation Index (SOI) (Lee et al., 2010). In this study, an ENSO proxy based on the anomalies of the Niño 3.4 index (http://www.cpc.ncep.noaa. gov/data/indices/, last access: 30 April 2015) is employed to reveal ENSO signatures in tropospheric $\mathrm{O}_{3}$ time series. The combined fit of the proxy and its time derivative accounts for the time lag as shown in Eq. (5).

$\operatorname{ENSO}(t)=x\left(\mathrm{~N}_{34}(t)+\frac{\mathrm{dN}_{34}(t)}{\mathrm{d} t} \Delta(t)\right)$,

where $\mathrm{N}_{34}$ is the ENSO proxy and $\Delta(t)$ is the time lag. Therefore, to account for the non-linearity of $\frac{\mathrm{dN}_{34}(t)}{\mathrm{d} t}$, for selected cases, fits were repeated using time lags varying from 0 to 2 months. It was found that best results were obtained using a time lag of $X$ months, and this time lag was then adopted for all fits.

\section{Results and discussion}

\subsection{Global distribution of tropospheric $\mathrm{O}_{3}$}

Analysis of the global distribution of tropospheric $\mathrm{O}_{3}$ is important for the understanding of recent changes in $\mathrm{O}_{3}$ and its precursor emissions. The tropospheric $\mathrm{O}_{3}$ distribution reflects a balance between local production and destruction as well as atmospheric transport. Figure 1 shows the seasonal distribution of the global tropospheric $\mathrm{O}_{3}$ in DU retrieved from SCIAMACHY observations averaged over 2003-2011 for $5^{\circ}$ latitude $\times 5^{\circ}$ longitude bins (Ebojie, 2014; Ebojie et al., 2014). Seasonal averages of the TOC provide a good compromise between minimizing variability associated with shorter time period averages and, thus, reveal information on seasonal long-term $\mathrm{O}_{3}$ changes (Parrish et al., 2012; Ebojie, 2014).

In the tropics, TOC in the top left panel of Fig. 1 for December-February shows a characteristic tropospheric $\mathrm{O}_{3}$ wave-one feature, which is persistent in the southern tropics, with higher TOC values ( $>40 \mathrm{DU}$ ) over the southern Atlantic tropics than the southern Pacific, as reported elsewhere (e.g. Fishman et al., 1990; Ebojie, 2014). This feature is observed in all seasons and is maximum in SeptemberNovember, with tropospheric $\mathrm{O}_{3}$ values greater than $40 \mathrm{DU}$ as compared to TOC values of less than $30 \mathrm{DU}$ over the southern Pacific (Ebojie, 2014). The wave-one pattern in TOC originates from different contributing factors including biomass burning and lightning in both Africa and South America, and deep convection in the Pacific region coupled with vertical injection of low marine boundary layer tropospheric $\mathrm{O}_{3}$ into the middle and upper troposphere (the largescale Walker circulation) (e.g. Fishman et al., 1990; Chandra et al., 2003; Sauvage et al., 2007b). In the top right panel of Fig. 1, which corresponds to TOC for June-August, largest TOC values ( $>45 \mathrm{DU})$ occur in the $\mathrm{NH}$ extratropics, with a corresponding enhancement of TOC values ( $>35 \mathrm{DU})$ in the tropical/subtropical southern Atlantic region. The high level of tropospheric $\mathrm{O}_{3}$ during boreal summer is primarily photochemically produced from anthropogenic pollution, biogenic VOCs and $\mathrm{NO}_{x}$ (e.g. Chandra et al., 2004). Pollution effects with sources from STE, biomass burning and lightning also play a role during this season of the year, as reported by many sources (e.g. Pfister et al., 2008; Thompson et al., 2008; Chandra et al., 2004). During March-May, i.e. the bottom left panel of Fig. 1, NH springtime TOC buildup is observed. The high tropospheric $\mathrm{O}_{3}$ values ( $>45 \mathrm{DU}$ ) in the northern subtropics and mid-latitudes are associated primarily with STE processes, which have an annual maximum in these zonal bands (e.g. Chandra et al., 2004). Also of importance to the enhancement of $\mathrm{O}_{3}$ in these zonal bands are tropospheric $\mathrm{O}_{3}$ production sources including lightning, combustion of fossil fuels, biomass burning and soil emissions (e.g. Pfister et al., 2008; Thompson et al., 2008). There is a shift in the seasonal cycle from summer maximum to 

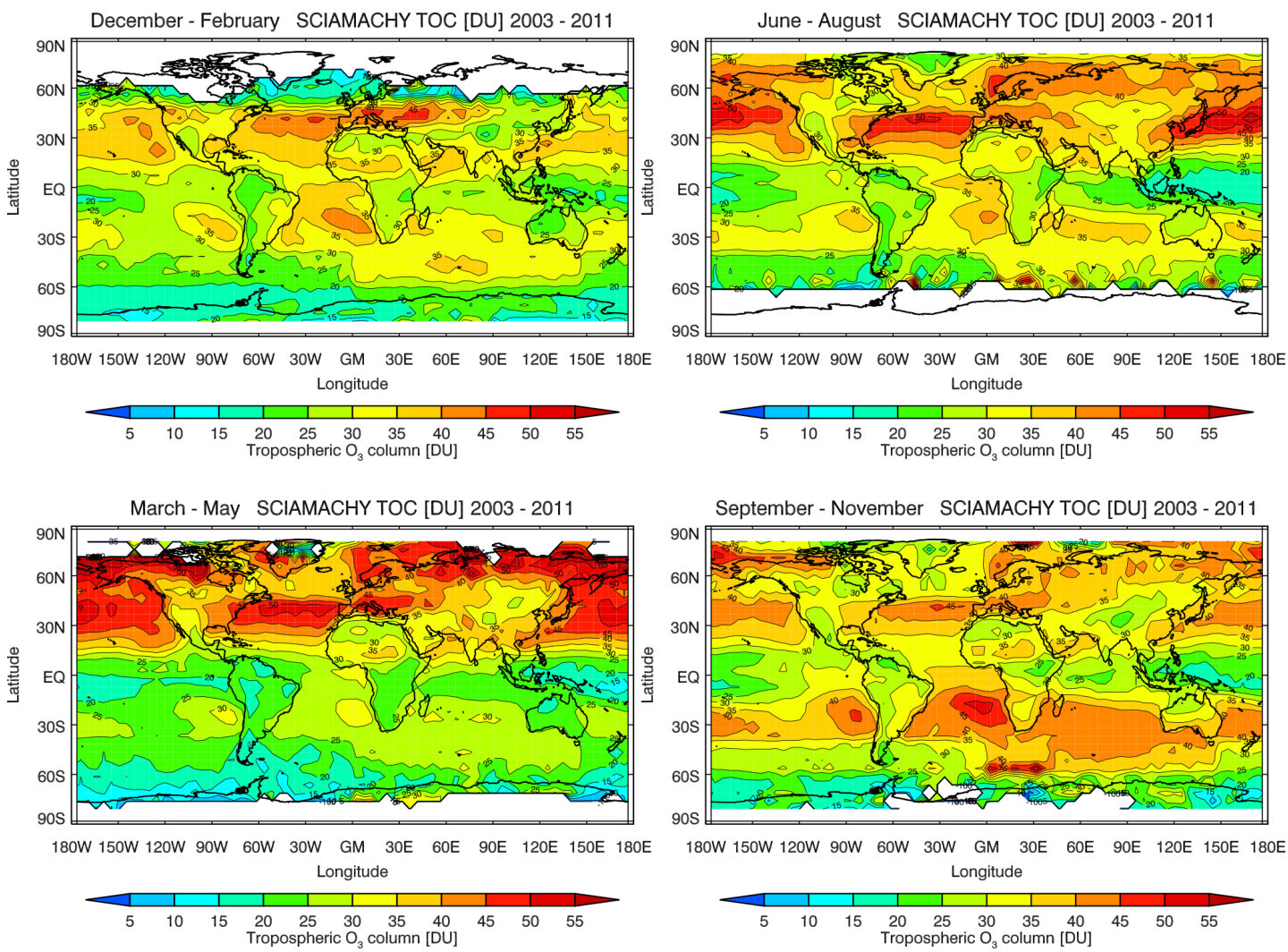

Figure 1. Global seasonal distribution of tropospheric $\mathrm{O}_{3}$ in DU from 2003 to 2011 for $5^{\circ}$ latitude $\times 5^{\circ}$ longitude bins. For latitudes above about $60^{\circ}$ in each hemisphere, $\mathrm{O}_{3}$ columns are only observed during summer.

spring-summer peak, mostly over the northern mid-latitudes, which can be attributed to either emission reductions over the region or an increase in springtime $\mathrm{O}_{3}$ or both, as reported elsewhere (e.g. Parrish et al., 2013; Cooper et al., 2014). In the bottom right panel of Fig. 1, corresponding to TOC for September-November, the high TOC values ( $>40 \mathrm{DU}$ ) that lie along a zonal band of approximately $30-50^{\circ} \mathrm{S}$ in the Southern Hemisphere ( $\mathrm{SH}$ ) are similar to the high values observed at the NH mid-latitudes during summer and spring. These seasonal enhancements in TOC are of dynamical origin caused by STE (e.g. de Laat et al., 2005).

\subsection{Global wind distribution}

A good knowledge of the global wind distribution is necessary for the interpretation of changes in global tropospheric $\mathrm{O}_{3}$, as it reveals information on the continental outflow and intercontinental transport of $\mathrm{O}_{3}$ pollution. Variation in wind speed and direction can favour tropospheric $\mathrm{O}_{3}$ variability. Changes in tropospheric $\mathrm{O}_{3}$ are not only a consequence of chemical reactions, but are also greatly affected by tropospheric circulation. Figure 2 shows contour plots of the global distribution of the seasonal wind speed in $\mathrm{m} \mathrm{s}^{-1}$ at $500 \mathrm{hPa}$ averaged over the years 2003-2011, which is overlaid with arrows (in blue) depicting wind direction. The plots are based on the ECMWF (European Centre for MediumRange Weather Forecasts) Reanalysis Interim (ERA-I) wind data for $1.5^{\circ}$ latitude $\times 1.5^{\circ}$ longitude bins regridded to $5^{\circ}$ latitude $\times 10^{\circ}$ longitude bins for better identification of the magnitude and direction of the wind. The plots show that, in the free troposphere, the easterlies prevail in the tropics, while westerlies prevail in the extratropics. Low wind speeds of less than $9 \mathrm{~m} \mathrm{~s}^{-1}$ dominate the tropics, with wind speeds of less than $6 \mathrm{~m} \mathrm{~s}^{-1}$ observed across parts of South America, the Atlantic Ocean, Africa, the Indian Ocean and the maritime Southeast Asia region. This shows the manifestation of the ITCZ (Intertropical Convergence Zone, Trenberth et al., 2000). Three semi-permanent year-round high-pressure centres in the southern oceans including the Indian, Pacific and Atlantic oceans, which peak mostly during boreal winter, are observed.

In the top left panel of Fig. 2, which corresponds to the wind distribution for December-February, high wind speed greater than $24 \mathrm{~m} \mathrm{~s}^{-1}$ is observed over the North Atlantic and North Pacific oceans. A corresponding high wind speed appears over the southern extratropics, mostly in the $30-60^{\circ} \mathrm{S}$ latitude bands. During boreal summer (June-August), which is shown in the top right panel of Fig. 2, a high wind speed greater than $18 \mathrm{~m} \mathrm{~s}^{-1}$ is observed over the southern extratropics, with the highest wind speed greater than $24 \mathrm{~m} \mathrm{~s}^{-1}$ 

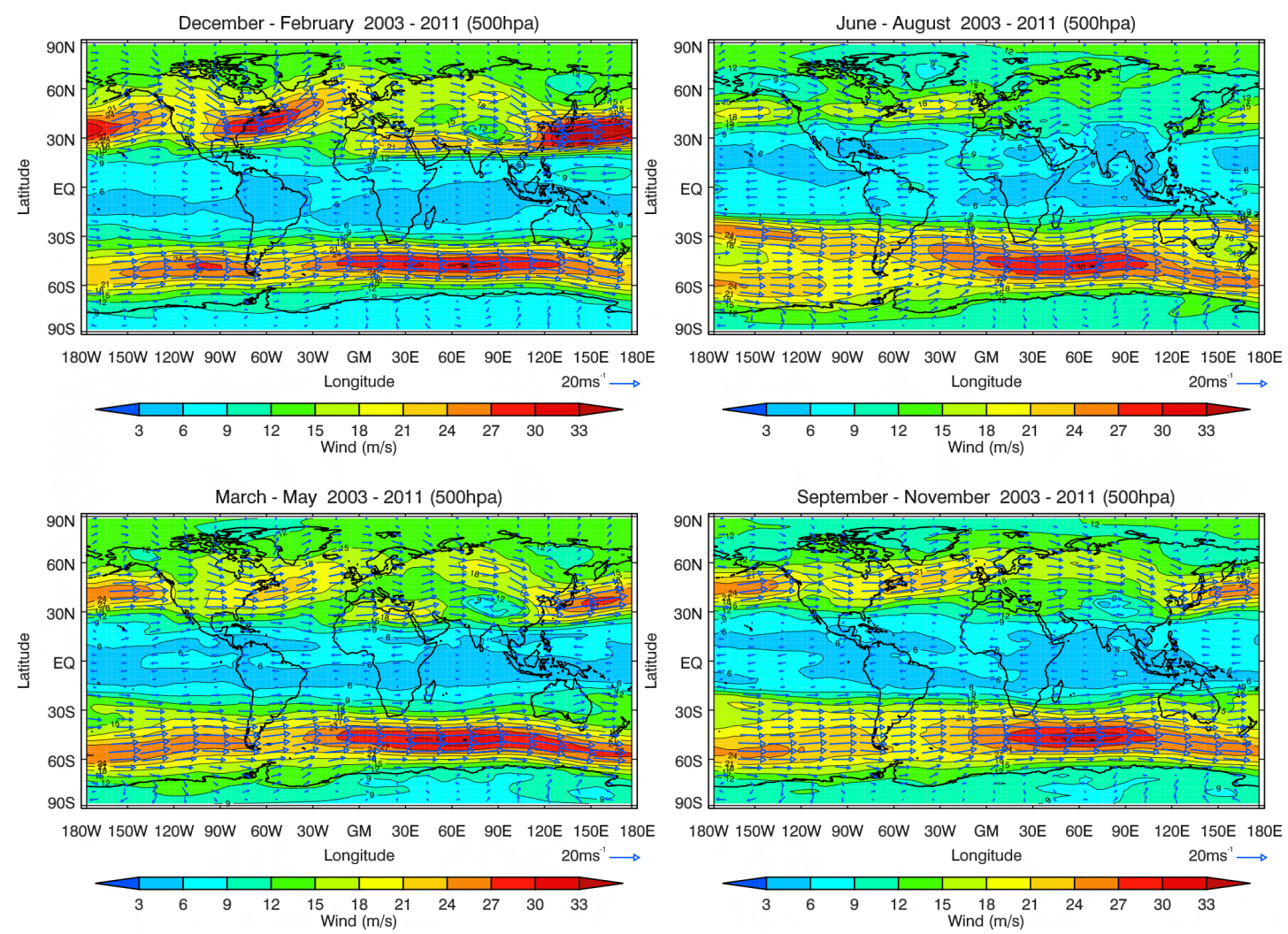

Figure 2. Global seasonal distribution of the $500 \mathrm{hPa}$ winds from the ECMWF (European Centre for Medium-Range Weather Forecasts) Reanalysis Interim (ERA-I) wind data from 2003 to 2011 for $5^{\circ}$ latitude $\times 10^{\circ}$ longitude bins.

occurring in the region $40-60^{\circ} \mathrm{S}$ and $35^{\circ} \mathrm{W}-100^{\circ} \mathrm{E}$. During boreal summer, there are less frequent cyclones in the northern mid-latitude, and the high-pressure belt in the southern subtropics extends northward. In the bottom left panel of Fig. 2, which corresponds to the wind distribution for March-May, frequent storms similar to those observed in the NH in December-February are observed. Highest wind speeds greater than $24 \mathrm{~m} \mathrm{~s}^{-1}$ are observed in the $\mathrm{SH}$ in the region $30-60^{\circ} \mathrm{S}$ and $30^{\circ} \mathrm{W}-180^{\circ} \mathrm{E}$ as well as in some regions of eastern Asia. During boreal autumn (SeptemberNovember), which is shown in the bottom right panel of Fig. 2, wind speed greater than $21 \mathrm{~m} \mathrm{~s}^{-1}$ occurs in some regions of the $\mathrm{NH}$, with the highest wind speed greater than $24 \mathrm{~m} \mathrm{~s}^{-1}$ occurring in the SH in the region $30-60^{\circ} \mathrm{S}$ and $20^{\circ} \mathrm{W}-100^{\circ} \mathrm{E}$. Similar wind patterns are observed in both hemispheres of March-May and September-November as shown in the bottom left and right panels of Fig. 2, respectively. Some localized areas of high wind speed appear over the North Atlantic and North Pacific around the Gulf of Alaska, which are produced by tropical cyclones. An asymmetry in the winter to summer variation between the two hemispheres is observed. The largest seasonal variations in wind speed occur in the $\mathrm{NH}$ oceans, mostly over the northern Atlantic. In contrast, the winter to summer variation in wind speed over the SH oceans is relatively small. The highest wind speeds greater than $24 \mathrm{~m} \mathrm{~s}^{-1}$ appear in the southern extratropics in all seasons, with corresponding high wind speed in the northern extratropics during boreal winter, spring and autumn. These bands of high wind speed are associated with mid-latitude winter storms (e.g. Romanski et al., 2014). Sudden reversal or change in wind direction is observed in all seasons between latitudes $15^{\circ}$ and $35^{\circ}$ in both hemispheres. This shows the manifestation of subtropical highs, which have been observed to have shifted due to direct radiative forcing from greenhouse gases among other processes (e.g. Hudson, 2012).

Wind distribution governs changes in the transport of $\mathrm{O}_{3}$ and its precursors. For instance, the middle-upper tropospheric anticyclone due to response to the thermal and orographic forcing of the Tibetan Plateau has a great impact on the atmospheric circulation in the $\mathrm{NH}$ (e.g. Ye and Wu, 1998; Zhang et al., 2005). The trans-Pacific transport of Asian pollution can influence changes in $\mathrm{O}_{3}$ over North America and the oceanic regions (e.g. Jaffe et al., 1999; Parrish et al., 2012; Cooper et al., 2014), variation in the trans-Atlantic transport of North American pollution can influence pollution over Europe as well as the Atlantic oceanic region (e.g. Derwent et al., 1998; Logan et al., 2012), and trans-Eurasian transport of European pollution can influence changes in $\mathrm{O}_{3}$ over Asia (e.g. Liu et al., 2002; Parrish et al., 2012). The 


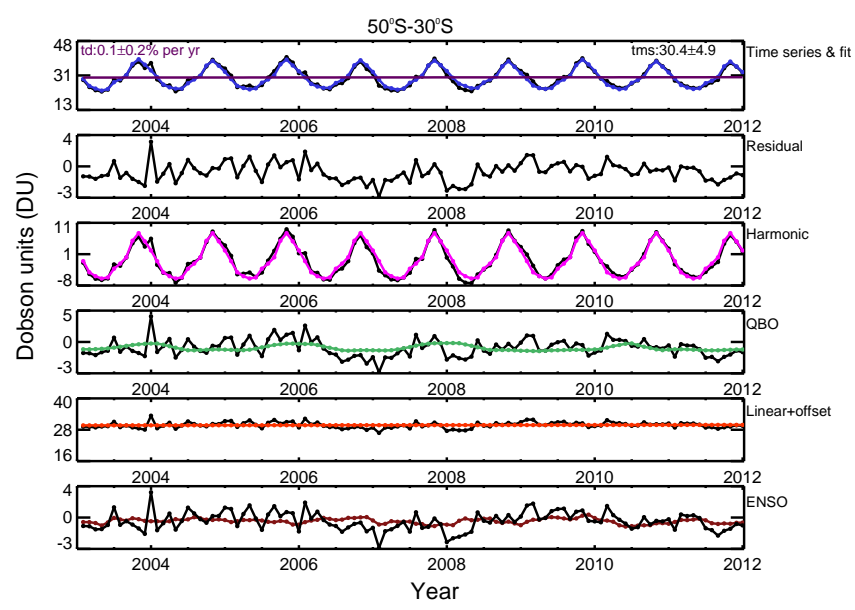

Figure 3. Time series (in Dobson units (DU)) from SCIAMACHY for $50-30^{\circ} \mathrm{S}$ (black) with overlaid fitting curve (blue in top panel) and fit residuals (second panel). Below, the individual components of the multi-variate linear regression are shown (from top to bottom): harmonic (pink), QBO (light green), linear change (orange), and ENSO (brown). Each of these terms is overlaid by the time series with all other components of the fitting curve subtracted.

vertical wind velocity in the middle troposphere plays a significant role in controlling the amount of $\mathrm{O}_{3}$ in the lower troposphere (Kim and Newchurch, 1996). Analysis shows that the centers of high velocity potential are associated with convergent inflow winds. The convergence in the upper troposphere corresponds to divergence in the lower troposphere, which is associated with downward vertical motion at the mid-troposphere. On the opposite side, a low velocity results in a vertical upward motion in the troposphere. Centers of lower tropospheric convergence and upper tropospheric divergence over the equatorial western Pacific are characterized by strong upward velocity in the mid-troposphere, with maximum upward velocity outside the equatorial regions. The equatorial eastern Pacific is associated with upper tropospheric convergence, lower tropospheric divergence, and mid-tropospheric downward vertical motion (Wang, 2005). These are consistent with Pacific climate features of the western Pacific warm pool and the equatorial eastern Pacific cold tongue.

\subsection{Zonal mean tropospheric $\mathrm{O}_{3}$ changes}

$\mathrm{O}_{3}$ trends are caused by long-term changes in chemistry or dynamics or both. Zonal mean time series of monthly averaged tropospheric $\mathrm{O}_{3}$ over four latitude bands $\left(50-30^{\circ} \mathrm{S}\right.$, $20^{\circ} \mathrm{S}-0,0-20^{\circ} \mathrm{N}$ and $30-50^{\circ} \mathrm{N}$ ) are displayed in Figs. 36 , with the time labeling on the $x$ axis corresponding to the first month of the year. The TOC time series (black) are overlaid with their fitting curves (blue) and linear term plus offset (hereinafter referred to as the linear term, (violet)) from the regression model. The fit residuals are shown below the

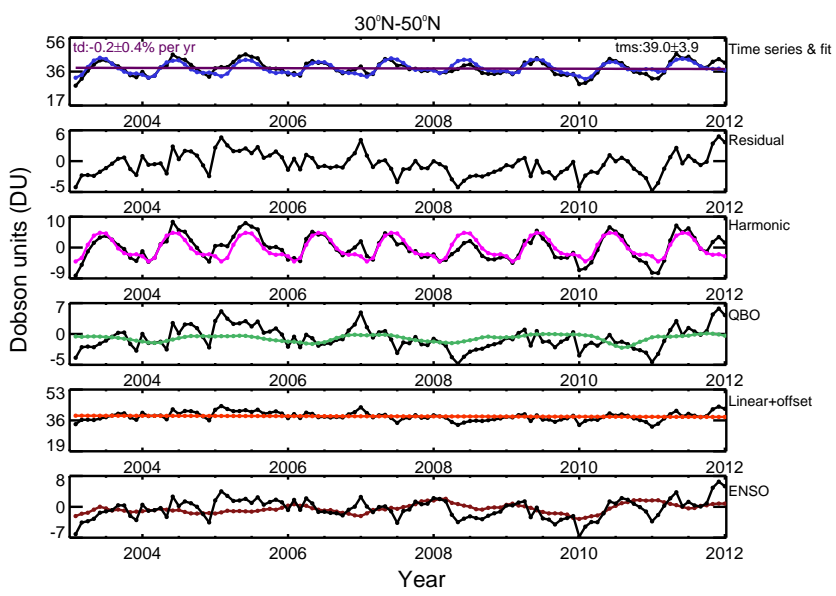

Figure 4. Same as Fig. 3 but for $30-50^{\circ} \mathrm{N}$.

TOC time series. The individual terms from the regression, including the harmonics, QBO, linear and ENSO terms, are shown in the panels below, respectively. The time series of the fit parameters are coloured differently, i.e. pink, green, orange, and brown representing the harmonic, QBO, linear and ENSO terms, respectively, while the overlaid time series in black represents the time series with all fit terms removed except the particular fit parameter.

Good fit quality is obtained in all four latitude bands. The fit residuals are typically of the order of a few DU. The annual cycles make comparable contributions to the fitting curves in all four latitude bands. The harmonic terms show high values during hemispheric spring and summer in Figs. 3 and 4, which represent $50-30^{\circ} \mathrm{S}$ and $30-50^{\circ} \mathrm{N}$ latitude bands, respectively. Figures 5 and 6 show TOC changes in the latitude bands $20^{\circ} \mathrm{S}-0$ and $0-20^{\circ} \mathrm{N}$, respectively. We separated the southern tropics from the northern tropics due to the seasonal shift in TOC distributions in the tropics also reported in other studies (e.g. Valks et al., 2014; Ziemke et al., 2014). In Fig. 5, the harmonic terms show high values mainly during austral spring-summer. The $\mathrm{O}_{3}$ maxima observed in Fig. 5 during austral spring-summer can be attributed mainly to transport of pollution and photochemical production of $\mathrm{O}_{3}$. The combination of emissions from extensive biomass burning and transport of upper tropospheric $\mathrm{O}_{3}$ production from lightning $\mathrm{NO}_{x}$, especially in the southern tropics, can contribute to the observed $\mathrm{O}_{3}$ maxima in the top panel of Fig. 5. Such tropospheric $\mathrm{O}_{3}$ maxima have been observed during austral spring-summer in several studies (e.g. Sauvage et al., 2007b; Randel and Thompson, 2011; Thompson et al., 2014; Ziemke et al., 2014; Ebojie et al., 2014; Ebojie, 2014). The QBO fit captures the interannual variability in the regression analysis better in Fig. 5 than in Fig. 6, while the reverse is the case for the ENSO fit. The tropospheric $\mathrm{O}_{3}$ seasonal cycle in the tropical region is primarily governed by two processes: the seasonal migration of the ITCZ and the photochemical production of $\mathrm{O}_{3}$ from 


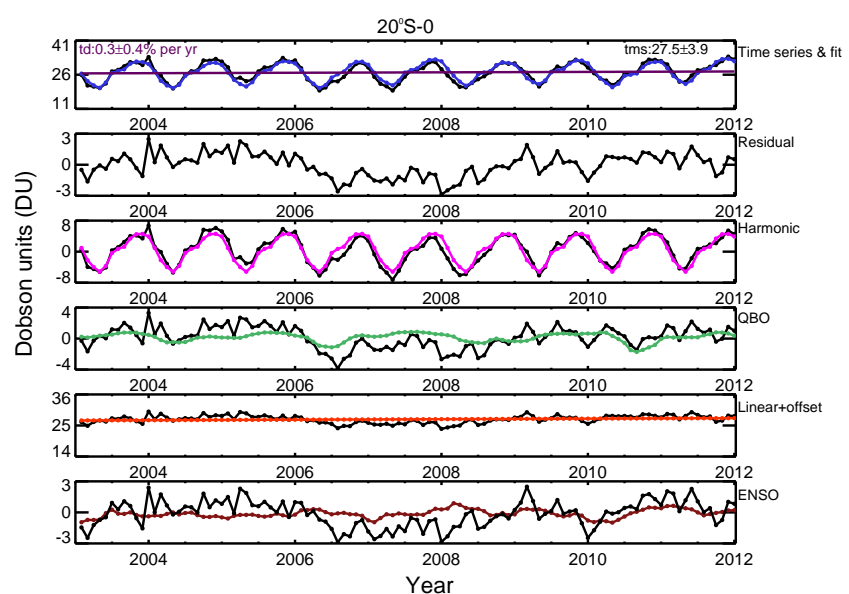

Figure 5. Same as Fig. 3 but for $20^{\circ} \mathrm{S}-0$.

Table 1. Trend analysis results for SCIAMACHY tropospheric $\mathrm{O}_{3}$ for different latitude ranges. Also included are mean values and standard deviation over the entire time series.

\begin{tabular}{lcc}
\hline Lat. range & Mean value and SD (DU) & Trend $\left(\% \mathrm{yr}^{-1}\right)$ \\
\hline $70-50^{\circ} \mathrm{S}$ & $24.8 \pm 3.7$ & $0.0 \pm 0.3$ \\
$50-30^{\circ} \mathrm{S}$ & $30.4 \pm 4.9$ & $0.1 \pm 0.2$ \\
$30-10^{\circ} \mathrm{S}$ & $31.1 \pm 4.7$ & $0.3 \pm 0.3$ \\
$10^{\circ} \mathrm{S}-10^{\circ} \mathrm{N}$ & $26.1 \pm 3.1$ & $0.1 \pm 0.5$ \\
$20^{\circ} \mathrm{S}-0$ & $27.5 \pm 3.9$ & $0.3 \pm 0.4$ \\
$0-20^{\circ} \mathrm{N}$ & $29.3 \pm 2.7$ & $0.1 \pm 0.5$ \\
$10-30^{\circ} \mathrm{N}$ & $33.9 \pm 2.6$ & $0.2 \pm 0.5$ \\
$30-50^{\circ} \mathrm{N}$ & $39.0 \pm 3.9$ & $-0.2 \pm 0.4$ \\
$50-70^{\circ} \mathrm{N}$ & $35.9 \pm 6.3$ & $-0.4 \pm 0.4$ \\
\hline
\end{tabular}

biomass burning and lightning activity (Moxim and Levy II, 2000; Thompson et al., 2000). These processes lead to atmospheric layers with strongly enhanced $\mathrm{O}_{3}$ volume mixing ratios and hence the TOCs. The $\mathrm{O}_{3}$ maxima observed in the subtropics and mid-latitudes of both hemispheres (top panels of Figs. 3 and 4) can be associated with the combination of transport of $\mathrm{O}_{3}$ and its precursors, local or regional photochemical production of $\mathrm{O}_{3}$ as well as stratospheric intrusion of $\mathrm{O}_{3}$-rich air masses into the troposphere (Chandra et al., 2004; Stohl et al., 2007; Pfister et al., 2008). The intercontinental transport of $\mathrm{O}_{3}$ and its precursors can also contribute to the observed changes in tropospheric $\mathrm{O}_{3}$ (Wild and Akimoto, 2001; Stohl et al., 2007; Cooper et al., 2012). In the southern subtropics and mid-latitudes, the influence of both stratospheric intrusion and emissions from biomass burning (e.g. Sauvage et al., 2006; Wai et al., 2014) plays a key role in the observed $\mathrm{O}_{3}$ maxima during austral spring in Fig. 3. The QBO fit does not capture a significant contribution of the interannual variability in the regression analysis as observed in Figs. 3 and 4. The possible ENSO contributions are better identified in Fig. 4 than in Fig. 3.

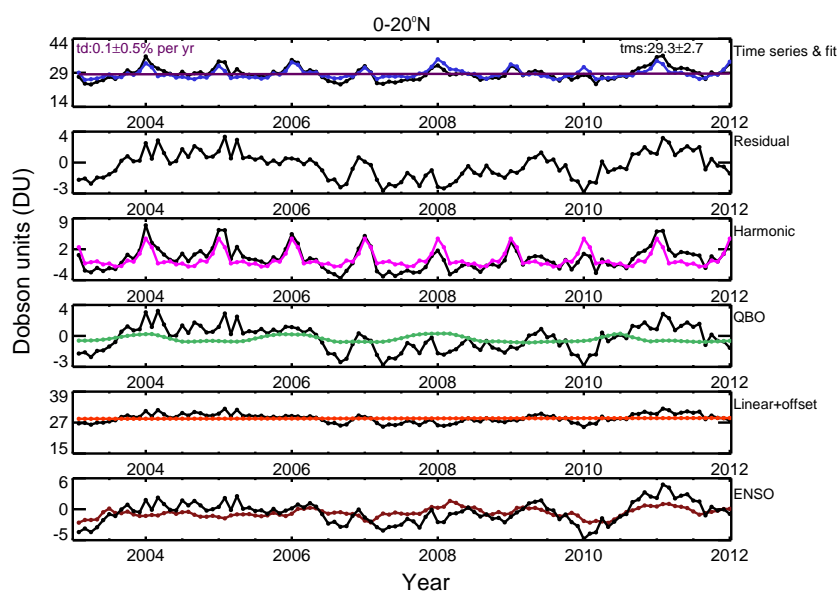

Figure 6. Same as Fig. 3 but for $0-20^{\circ} \mathrm{N}$.

Table 1 shows the results of zonal mean TOC trends, the mean values and standard deviation. An insignificant increase in tropospheric $\mathrm{O}_{3}$ of $0.1 \pm 0.2 \% \mathrm{yr}^{-1}$ with a mean value of $30.4 \pm 4.9 \mathrm{DU}$ is observed in the $50-30^{\circ} \mathrm{S}$ latitude band (Fig. 3). This region is mainly over the ocean with less influence from land; hence, there is uniformity in $\mathrm{O}_{3}$ distributions in this zonal band as observed in Ebojie (2014) and in Fig. 12 of Ebojie et al. (2014). The observed insignificant positive change in $\mathrm{O}_{3}$ in this zonal band may be due to a larger contribution of the significant positive change in TOC over southern South America compared to the significant negative change or no trend over the oceans as shown in Fig. 10.

A statistically insignificant decrease in TOCs of $-0.2 \pm$ $0.4 \% \mathrm{yr}^{-1}$ with a mean value of $39.0 \pm 3.9 \mathrm{DU}$ is observed between 30 and $50^{\circ} \mathrm{N}$ (Fig. 4). This zonal band is greatly influenced by land-sea contrast in tropospheric $\mathrm{O}_{3}$ and anthropogenic activity. The observed insignificant decrease in TOC over this latitude band could be associated with stronger significant negative TOC changes over Europe and North America than the significant positive change over northern China as observed in Fig. 10. Similar negative trends in TOC over Europe and North America have been observed in other studies (e.g. Parrish et al., 2012; Vestreng et al., 2009; Cooper et al., 2012, 2014).

In the $20^{\circ} \mathrm{S}-0$ latitude band (Fig. 5), an insignificant positive change in tropospheric $\mathrm{O}_{3}$ of $0.3 \pm 0.4 \% \mathrm{yr}^{-1}$ with a mean value of $27.5 \pm 3.9 \mathrm{DU}$ is observed. The insignificant positive change in ozone in this region may be a consequence of a larger contribution by significant positive change in TOC over southern Africa and northern Australia outflow compared to the small significant negative change in TOC or no trend over the oceans. The significant positive changes observed over southern Africa and the northern Australian outflow region as shown in Fig. 10 may be a result of changes in $\mathrm{O}_{3}$ precursor emission from anthropogenic activities. Changes in atmospheric circulation and emissions 


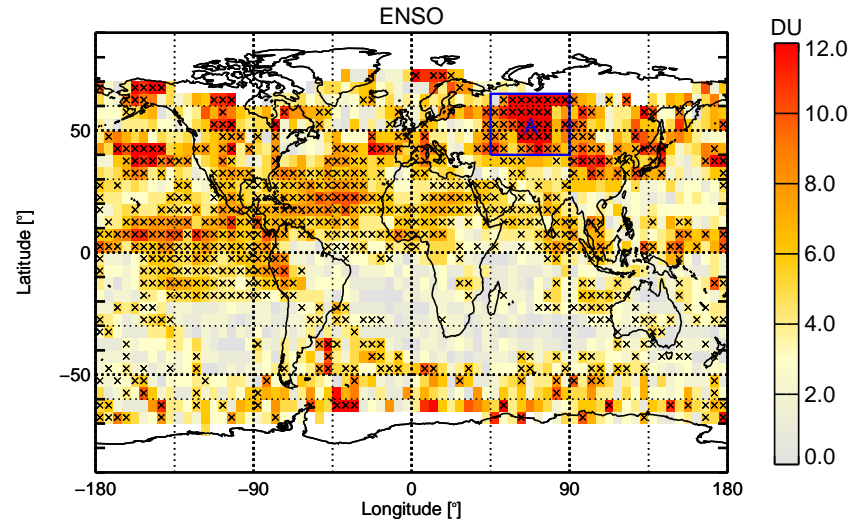

Figure 7. Maximum ENSO response (in Dobson units (DU)) to changes in SCIAMACHY tropospheric $\mathrm{O}_{3}$ columns derived for the period 2003-2011 resolved in $5^{\circ} \times 5^{\circ}$ bins. The maximum response is derived from the difference between the maximum and minimum of the ENSO term in the regression. The regions with crosses indicate grid boxes where the ENSO regression coefficient is statistically significant to $2 \sigma$. The square with label "A" over Eurasia marks a region for which a TOC trend was calculated (see main text).

from biomass burning may also have contributed to the observed positive change in $\mathrm{O}_{3}$ in this latitude band (Randel and Thompson, 2011; Thompson et al., 2014). In the $0-20^{\circ} \mathrm{N}$ latitude band corresponding to Fig. 6, an insignificant change in tropospheric $\mathrm{O}_{3}$ of $0.1 \pm 0.5 \% \mathrm{yr}^{-1}$ with a mean value of $29.3 \pm 2.7 \mathrm{DU}$ is observed. The small positive trend in TOC over this region results from many small positive and negative trends, most of which are statistically insignificant, as observed in Fig. 10.

\subsection{QBO and ENSO responses to changes in tropospheric ozone column}

The contributions of the proxies used in the regression analysis were tested to show their response to changes in tropospheric $\mathrm{O}_{3}$. Figures 7 and 8 show ENSO and QBO responses to changes in TOC for the period 2003-2011, respectively. They are derived by subtracting the minimum from the maximum proxy response in the time series for each grid box. The regions marked with crosses represent fitting coefficients of the proxy or, in the case of QBO, at least where one of the coefficients is statistically significant at the $95 \%$ confidence level. In Fig. 7, extensive regions of significant ENSO responses in TOC extending from the equatorial to $\mathrm{NH}$ middle latitude regions are observed. These may be the response of tropospheric circulations and/or troposphere-stratospheretroposphere events connected with ENSO changes (e.g. Reichler et al., 2005; Graf and Zanchettin, 2012; Butler et al., 2014), which occur mainly at middle and high latitudes, particularly in the NH. Significant ENSO signals have been observed in some tropical and extratropical regions in previ-

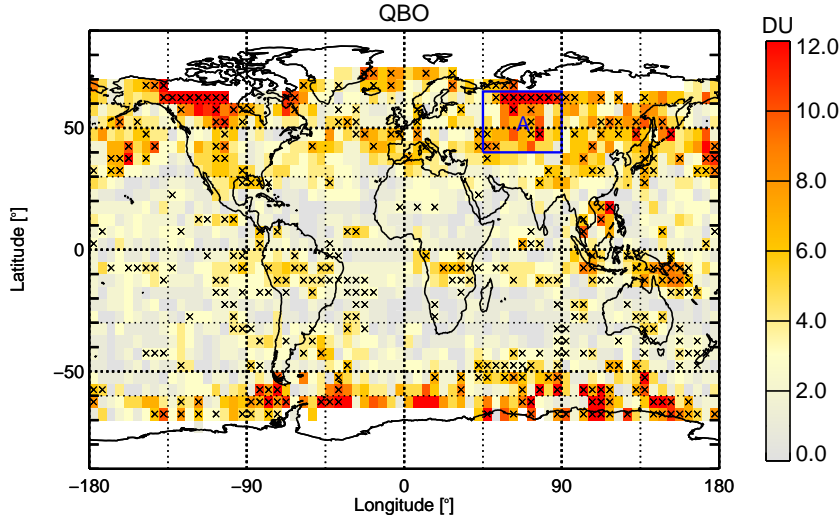

Figure 8. Same as Fig. 7 but for QBO. Here the maximum response is derived from the sum of the two QBO terms in the regression. The regions with crosses indicate grid boxes where at least one of the QBO regression coefficients is statistically significant to $2 \sigma$.

ous studies (e.g. Trenberth et al., 1998; Hoerling et al., 1997; Neu et al., 2014; Oman et al., 2013; Trenberth et al., 2002; Ziemke et al., 2015; Graf and Zanchettin, 2012; Scaife et al., 2014; Butler et al., 2014), although with different amplitudes. The observed ENSO signals may be due to large-scale atmospheric circulation teleconnection patterns excited by tropical atmospheric heating anomalies (e.g. Horel and Wallace, 1981; Trenberth et al., 1998, 2002), which involve both a tropospheric and a stratospheric pathway. While ENSO's climate impacts over North America are largely associated with a tropospheric pathway, its climate impacts over the North Atlantic and Eurasia are greatly affected by a stratospheric pathway (e.g. Graf and Zanchettin, 2012; Butler et al., 2014). The tropospheric pathway involves poleward propagating Rossby waves generated by anomalous atmospheric heating at equatorial latitudes, which may be trapped by the subtropical jet and propagate eastward within the subtropical waveguide (e.g. Trenberth et al., 1998, 2002; Graf and Zanchettin, 2012). Changes in the mid-latitude storm tracks during El Niño events can alter the vorticity flux by transient synoptic eddies, thus modulating the amplitude and structure of the extratropical planetary-scale wave trains initiated by tropical sea surface temperature anomalies. The stratospheric pathway consists of planetary waves that propagate primarily upwards, greatly perturbing the stratosphere and occasionally producing extreme events such as the sudden stratospheric warmings, which subsequently affect surface conditions below, primarily in the North Atlantic region and Eurasia (e.g. Brönnimann et al., 2004; Bell et al., 2009; Cagnazzo and Manzini, 2009; Ineson and Scaife, 2009; Butler et al., 2014).

In Fig. 8, significant QBO signals are observed in some regions at the tropics and high latitudes. Neu et al. (2014) observed the influence of QBO on TOC changes in the midlatitudes of the $\mathrm{NH}$. The significant QBO signals at the high latitudes, particularly the northern high latitudes, could be a 


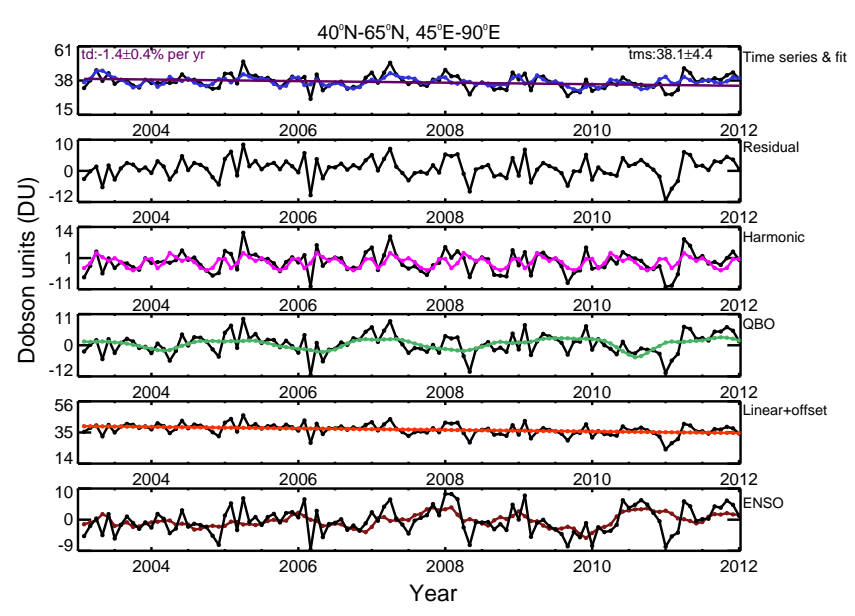

Figure 9. Same as Fig. 3 but for the regions $40-65^{\circ} \mathrm{N}$ and $45-90^{\circ} \mathrm{E}$ as marked in Figs. 7 and 8.

result of the strengthening of the polar vortex, which is associated with a positive phase in the North Atlantic Oscillation, mostly during boreal winter (e.g. Thompson et al., 2001; Scaife et al., 2014). The observed QBO signal may also be due to several mechanisms, including anomalies in convection (e.g. Collimore et al., 2003), the meridional circulation that maintains thermal wind balance with $\mathrm{QBO}$ equatorial stratospheric wind anomalies, which interacts with the troposphere, or due to tropospheric eddies (e.g. Randel et al., 1999; Garfinkel and Hartmann, 2011). Both strong QBO and ENSO signals can be observed over some regions of the southern Pacific, southern Atlantic, southern Indian Ocean, Siberia, eastern Asia, North America and the western Pacific mostly around Indonesia, with the ENSO signal being generally higher than the QBO signal. Figure 9 is extracted from one of the regions in the NH of Fig. 7, which is denoted by A, where high values of the ENSO and QBO coefficients are observed. In this region, a maximum response of ENSO of 4.7 DU and a minimum of about $-5.2 \mathrm{DU}$ (maximum difference $=9.9 \mathrm{DU}$ ) are observed, while the maximum and minimum responses of $\mathrm{QBO}$ of $2.6 \mathrm{DU}$ and $-5.2 \mathrm{DU}$ (maximum difference $=7.8 \mathrm{DU}$ ), respectively, are observed. The ENSO fit captures the interannual variability in the regression analysis better than the QBO fit. Also observed in the top panel of Fig. 9 is a significant negative change in TOC of $-1.4 \pm 0.4 \% \mathrm{yr}^{-1}$, which is also shown in Fig. 10 as discussed below.

\subsection{Global and regional mean tropospheric $\mathrm{O}_{3}$ changes}

\subsubsection{Changes in SCIAMACHY global tropospheric $\mathrm{O}_{3}$ columns}

The changes in tropospheric $\mathrm{O}_{3}$ are complex and vary both regionally and globally. They are strongly influenced by changes in precursor emissions, temperature, humidity, con-

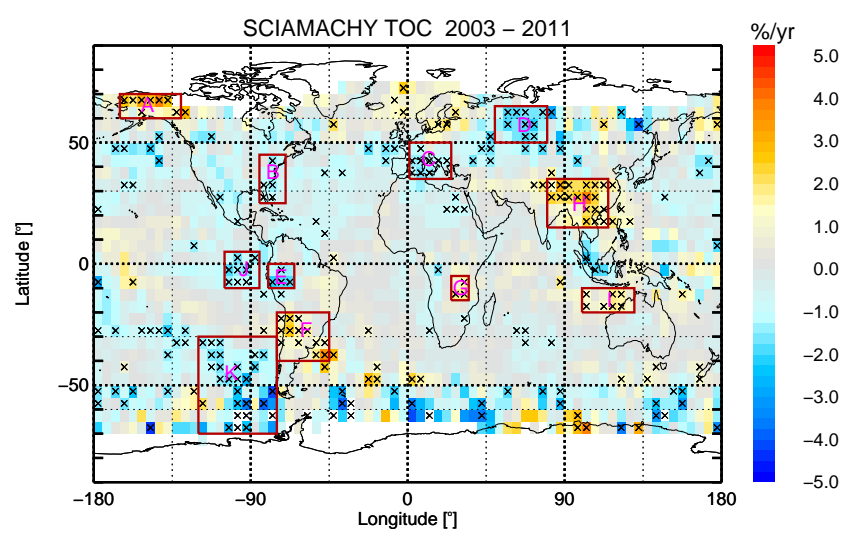

Figure 10. Changes in SCIAMACHY tropospheric $\mathrm{O}_{3}$ columns $\left(\% \mathrm{yr}^{-1}\right)$ derived for the period 2003-2011 with $5^{\circ}$ latitude $\times 5^{\circ}$ longitude resolutions. The regions with cross signs describe statistically significant change and the white coloured areas represent places with no trend data.

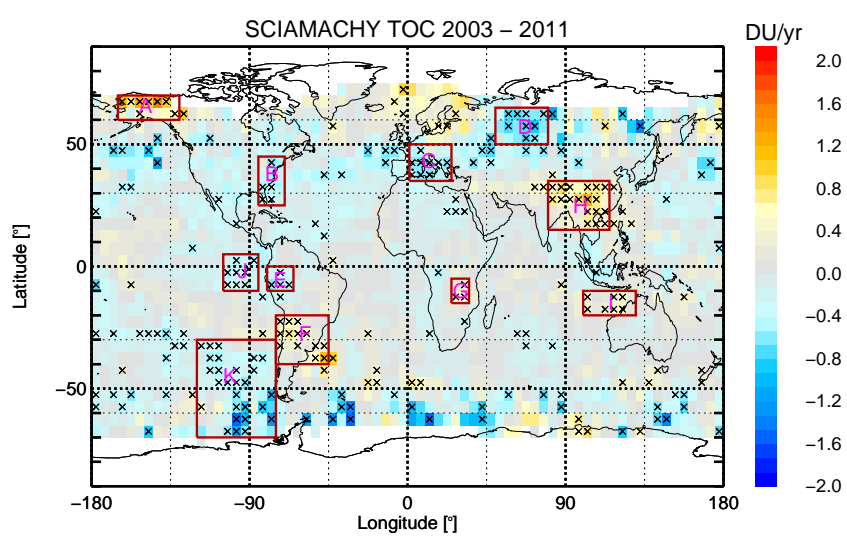

Figure 11. Same as Fig. 10 but for changes in units of $\mathrm{DU} \mathrm{yr}^{-1}$.

vection, STE, and hemispheric transport patterns. Figures 10 and 11 show global changes in SCIAMACHY TOC derived from 2003 to 2011 for $5^{\circ}$ latitude $\times 5^{\circ}$ longitude bins in $\% \mathrm{yr}^{-1}$ and $\mathrm{DU} \mathrm{yr}^{-1}$, respectively. The colour ranges from blue to red, representing negative to positive changes in TOCs from 2003 to 2011. The white coloured area represents places with no TOC data due to the applied data screening criteria described in Ebojie et al. (2014) and Ebojie (2014). In the determination of TOC from SCIAMACHY LNM observations (Ebojie et al., 2014; Ebojie, 2014), limb scenes that are contaminated with clouds and nadir measurements that have a cloud fraction of more than 0.1 were screened out. This makes it unlikely, although not impossible, that the derived trends may be significantly affected by possible changes in cloud parameters from 2003 to 2011. The errors of the derived changes in TOCs are estimated at $1 \sigma$ expressed in units of $\% \mathrm{yr}^{-1}$ and $\mathrm{DU} \mathrm{yr}^{-1}$. The regions marked with cross signs represent changes in tropospheric $\mathrm{O}_{3}$ significant at the $95 \%$ confidence level. 

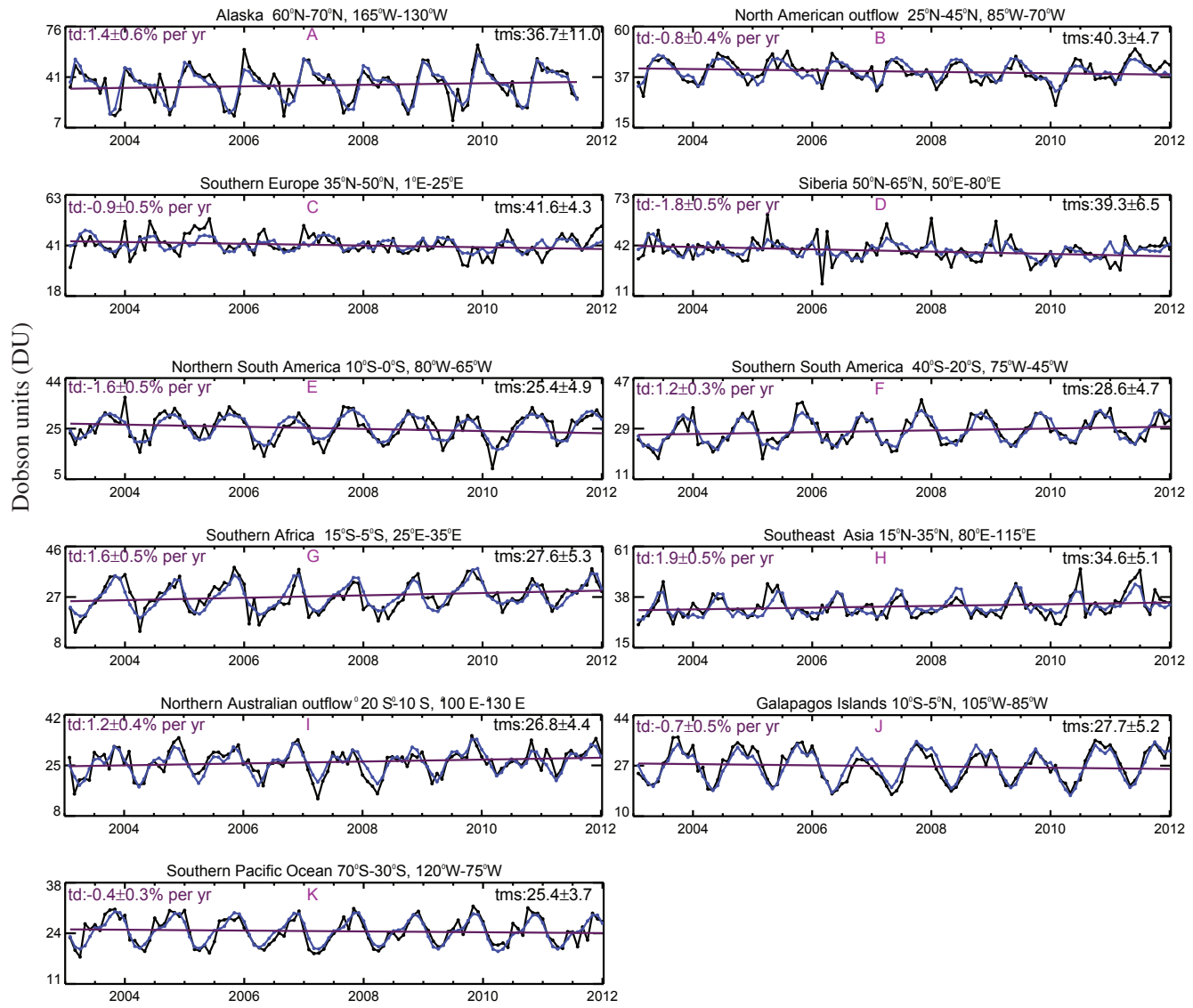

Year

Figure 12. Time series (in Dobson units (DU)) (black) from SCIAMACHY (for the different regions A-K shown in Figs. 10 and 11) with overlaid fitting curves (blue) and linear change plus offset (violet) for the period 2003-2011.

Changes in TOC are observed along the possible outflow from continents to oceanic regions. Statistically significant changes in tropospheric $\mathrm{O}_{3}$ are observed over the regions of North America, Europe, South Asia, South America and Africa. Significant changes in $\mathrm{O}_{3}$ are also observed over the clean and pristine marine region including the Pacific Ocean, Indian Ocean and Atlantic Ocean. The observed TOC changes might have been influenced by changes in transport of pollution, anthropogenic $\mathrm{O}_{3}$ precursor emissions and dynamical phenomena including ENSO, the North Atlantic Oscillation-Northern Annular Mode (NAO-NAM), Southern Annular Mode (SAM) in the extratropics, Pacific North American (PNA), Pacific Decadal Oscillation (PDO), Atlantic Multi-Decadal Oscillation (AMO), etc. (e.g. Handorf and Dethloff, 2009; Lin et al., 2014; Ziemke et al., 2015). The climate patterns associated with the modes may exhibit structural, spatial, index or no change (e.g. Compo and Sardeshmukh, 2010; Bulic and Kucharski, 2012). During El Niño events, the ITCZ is farther south and closer to the Equator, while during La Niña, it is farther north and away from the Equator (e.g. Hastenrath, 1977; Schneider et al., 2014).
These alter the strength of the tropical cyclones over the $\mathrm{Pa}$ cific and Indian oceans, thus influencing TOC changes. Close to the branches of the ITCZ in the Indian and Pacific oceans, and possibly close to the ITCZ in other regions, we observe significant linear trends for the analysis period 2003 to 2011. Generally air masses are different on the different sides of the ITCZ. Thus, they have different amounts of tropospheric $\mathrm{O}_{3}$. Our explanation of the observed linear trends is that the positions of the oceanic branches of the ITCZ, and perhaps also the ITCZ, have been changing (e.g. Hastenrath, 1977; Pike, 1971; Xie and Philander, 1994; Moxim and Levy II, 2000; Schneider et al., 2014). This may be induced from oscillations of the position of the ITCZ, produced by natural phenomena, or possibly an early warning of anthropogenically induced changes (e.g. Hastenrath, 1977; Xie and Tanimoto, 1998; Xie and Philander, 1994; Chang et al., 1997; Schneider et al., 2014). In general, changes in the position of the ITCZ, in addition to that simply expected seasonally, their origins and consequences for the production and removal of tropospheric $\mathrm{O}_{3}$ and other pollutants, require careful assessment in the future. Longer time series of data and more re- 
search are required to identify unambiguously the origin of these trends. Significant positive changes in $\mathrm{O}_{3}$ are observed over North America, especially around Alaska (region A in Fig. 10, up to $2 \% \mathrm{yr}^{-1}$ ), which may be attributed to changes in both transport of pollution and photochemical production of $\mathrm{O}_{3}$ from natural and anthropogenic precursor emissions. Significant negative TOC changes (up to $-3 \% \mathrm{yr}^{-1}$ ) are observed over some parts of North America, South America and Europe (regions B, C, D and E in Figs. 10 and 11), which can be attributed to a decrease in anthropogenic $\mathrm{NO}_{x}$ and VOC emissions as well as a reduction in other tropospheric $\mathrm{O}_{3}$ precursors (e.g. Vestreng et al., 2009; Logan et al., 2012). Increase in anthropogenic and biogenic halogens may also play a role in the observed significant negative change in TOC over North America and Europe (von Glasow et al., 2002; Read et al., 2008). Similar significant negative trends in tropospheric $\mathrm{O}_{3}$ have been observed in some earlier studies (e.g. Parrish et al., 2012, 2014). Significant negative TOC changes (up to $-2 \% \mathrm{yr}^{-1}$ ) are also observed over the marine regions of the Atlantic Ocean, the Pacific Ocean and the Indian Ocean. The significant negative TOC changes over these regions can be associated with an increased photochemical sink $\left(\mathrm{HO}_{x}\right.$ chemistry and photolysis of $\mathrm{O}_{3}$ to singlet $\mathrm{D}$ oxygen atoms $\left.\left({ }^{1} \mathrm{D}\right)\right)$ and dilution processes due to meteorological changes (Kley et al., 1997; Wai et al., 2014). The declining trend of tropospheric $\mathrm{O}_{3}$ over North America and Europe has also contributed to the negative TOC changes over the oceans, mostly over the outflow regions. Changes in organic and inorganic halogens may also play a role in the observed negative TOC changes over the oceanic regions (Dickerson et al., 1999; Read et al., 2008). Significant positive changes in tropospheric $\mathrm{O}_{3}$ are observed over some regions of South America (region $\mathrm{F}$ in Fig. 10, up to $2 \% \mathrm{yr}^{-1}$ ), South Asia (region $\mathrm{H}$ in Fig. 10, $1-3 \% \mathrm{yr}^{-1}$ ), part of Africa (region $\mathrm{G}$ in Fig. 10) and over the marine regions (up to $2 \% \mathrm{yr}^{-1}$ ). The observed significant positive changes in tropospheric $\mathrm{O}_{3}$ over South America, South Asia and part of Africa can be attributed to an increase in population, industrialization and energy consumption (e.g. Beig and Singh, 2007; Cooper et al., 2014). Changes in meteorology and intercontinental transport of pollution can also contribute to the observed changes in $\mathrm{O}_{3}$ over the regions of South America, South Asia and Africa (e.g. Lelieveld et al., 2004; Beig and Singh, 2007; Parrish et al., 2012). The significant change in $\mathrm{O}_{3}$ observed over the regions of the South Atlantic and southern South America can be attributed to changes in transport patterns, anthropogenic $\mathrm{NO}_{x}$ and other tropospheric $\mathrm{O}_{3}$ precursors (e.g. Schultz et al., 1999; Wai et al., 2014). In southern Africa, the widespread biomass burning events in Angola, Zambia and the Democratic Republic of Congo, particularly during July-September, lead to the formation of $\mathrm{O}_{3}$ precursors. The transport of $\mathrm{O}_{3}$ and its precursors by the prevailing wind systems over these regions leads to significant change in TOC (Sauvage et al., 2005, 2007a). For instance, the persistent low-level easterlies/southeasterlies in these regions facilitate the westward transport of tropospheric $\mathrm{O}_{3}$ and its precursors (see Fig. 2). The prevailing descending air masses and relatively low wind speeds over southern Africa, South America, the Atlantic Ocean and the Indian Ocean limit the dispersion of tropospheric $\mathrm{O}_{3}$ and its precursors produced from burning plumes in Africa and South America. The prevailing highpressure system over southern Africa leads to the recirculation of plumes of tropospheric $\mathrm{O}_{3}$ and its precursors over the continent before exiting from the southern or western parts of the continent to the Indian Ocean or the Atlantic Ocean south of the ITCZ, respectively (e.g. Edwards et al., 2006; Wai et al., 2014).

Biomass burning activities in South America, which peak from August to October, lead to formation of tropospheric $\mathrm{O}_{3}$ and its precursors. $\mathrm{O}_{3}$ and its precursors can remain in the planetary boundary layer before they are transported to the upper troposphere via deep convective processes (e.g. Wu et al., 2011; Sauvage et al., 2006). In the free troposphere, the $\mathrm{O}_{3}$ plumes can be effectively transported by westerlies through the continental outflows located southeast of South America (see Fig. 2). The significant increase in $\mathrm{O}_{3}$ (up to $2 \% \mathrm{yr}^{-1}$ ) observed over the northern Australia outflow (region I) can be associated with changes in the wind pattern. The significant increase in TOC over southern Asia can mainly be associated with changes in anthropogenically produced $\mathrm{O}_{3}$ precursors from both domestic and industrial combustion as well as biomass burning (Liu et al., 2002; Parrish et al., 2012). The $\mathrm{O}_{3}$ produced over these regions is transported towards the western Pacific Ocean by large-scale dynamics controlled by the prevailing wind systems. This can contribute to changes in TOC over some regions of the western Pacific Ocean. The variation in TOC changes observed over the southern high latitudes may be a consequence of gaps in the TOC time series due to the applied data screening criteria (Ebojie et al., 2014; Ebojie, 2014).

The uncertainties of the fit parameters are determined from the covariance matrix of the regression. The uncertainty in SCIAMACHY TOC has been discussed in detail by Ebojie et al. (2014) and Ebojie (2014). In addition to the regression uncertainties, trend uncertainties due to instrumental artefacts, e.g. scan mirror degradation, introducing potential drifts in the data, may also play a role, but the effect was found to be small (Bramstedt et al., 2009; Ebojie et al., 2014; Ebojie, 2014). Inspection of the colour map of the $\% \mathrm{yr}^{-1}$ and $\mathrm{DU} \mathrm{yr}^{-1}$ trend uncertainties (figures not shown) shows that the uncertainty in the $\mathrm{O}_{3}$ trend is generally below $1 \% \mathrm{yr}^{-1}$ and $0.5 \mathrm{DU} \mathrm{yr}^{-1}$ globally, respectively (Ebojie, 2014). The uncertainties in TOC changes become high at the southern high latitudes, probably due to gaps in data coverage associated with prevailing cloud cover and the variability of tropospheric ozone and its precursors in the region. 
Table 2. Trend analysis results for SCIAMACHY tropospheric $\mathrm{O}_{3}$ for different regions. Also included are mean values and standard deviation over the entire time series. Bold text indicates statistically significant changes in TOC.

\begin{tabular}{|c|c|c|c|c|}
\hline Region & Lat. range & Long. range & $\begin{array}{l}\text { Mean value and } \\
\text { SD (DU) }\end{array}$ & Trend $\left(\% \mathrm{yr}^{-1}\right)$ \\
\hline (A) Alaska & $60-70^{\circ} \mathrm{N}$ & $165-130^{\circ} \mathrm{W}$ & $36.7 \pm 11.0$ & $\mathbf{1 . 4} \pm \mathbf{0 . 6}$ \\
\hline (B) North American outflow & $25-45^{\circ} \mathrm{N}$ & $85-70^{\circ} \mathrm{W}$ & $40.3 \pm 4.7$ & $-0.8 \pm 0.4$ \\
\hline (C) Southern Europe & $35-50^{\circ} \mathrm{N}$ & $1-25^{\circ} \mathrm{E}$ & $41.6 \pm 4.3$ & $-0.9 \pm 0.5$ \\
\hline (D) Siberia & $50-65^{\circ} \mathrm{N}$ & 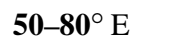 & $39.3 \pm 6.5$ & $-1.8 \pm 0.5$ \\
\hline (E) Northern South America & $10-0^{\circ} \mathrm{S}$ & $80-65^{\circ} \mathrm{W}$ & $25.4 \pm 4.9$ & $-1.6 \pm 0.5$ \\
\hline (F) Southern South America & 40-20 ${ }^{\circ} \mathrm{S}$ & $\mathbf{7 5}-\mathbf{4 5}{ }^{\circ} \mathrm{W}$ & $28.6 \pm 4.7$ & $1.2 \pm 0.3$ \\
\hline (G) Southern Africa & $15-5^{\circ} \mathrm{S}$ & $25-35^{\circ} \mathrm{E}$ & $27.6 \pm 5.3$ & $1.6 \pm 0.5$ \\
\hline (H) Southeast Asia & $15-35^{\circ} \mathrm{N}$ & $80-115^{\circ} \mathrm{E}$ & $34.6 \pm 5.1$ & $\mathbf{1 . 9} \pm \mathbf{0 . 5}$ \\
\hline (I) Northern Australia outflow & $20-10^{\circ} \mathrm{S}$ & $100-130^{\circ} \mathrm{E}$ & $26.8 \pm 4.4$ & $1.2 \pm 0.4$ \\
\hline (J) Galapagos Islands & $10^{\circ} \mathrm{S}-5^{\circ} \mathrm{N}$ & $105-85^{\circ} \mathrm{W}$ & $27.7 \pm 5.2$ & $-0.7 \pm 0.5$ \\
\hline (I) Southern Pacific Ocean & $70-30^{\circ} \mathrm{S}$ & $120-75^{\circ} \mathrm{W}$ & $25.4 \pm 3.7$ & $-0.4 \pm 0.3$ \\
\hline
\end{tabular}

\subsubsection{Regional mean tropospheric $\mathrm{O}_{3}$ changes}

Investigation of changes in the TOCs for some specific regions (Fig. 12), which are highlighted in Figs. 10 and 11, shows changes in TOCs over the years 2003-2011, which could be due to variations in meteorology and anthropogenic emissions of ozone precursors. In Table 2 and Fig. 12, 5 out of the 11 regions extracted from Fig. 10 show significant increase, 2 regions show significant decrease, while the remaining 4 regions show insignificant change in TOCs. The changes in TOCs over these regions could be attributed to variation in tropospheric background $\mathrm{O}_{3}$, temporal variation of precursor emissions, systematic changes in transport meteorology, as well as to the changes in photochemical oxidation and removal processes. Most of the regions show a pronounced seasonal cycle with maximum TOC values during hemispheric spring and summer with different amplitudes. Significant positive change and variability in the mean tropospheric $\mathrm{O}_{3}$ are observed over Alaska (region A). The significant positive change over this region could be a result of changes in precursor emissions from biomass burning (Stohl et al., 2007; Oltmans et al., 2010). Changes in transport of $\mathrm{O}_{3}$ and its precursors from the stratosphere or lower latitudes as well as the influence of rapid climate change may also play a role (Oltmans et al., 2013). The variability in TOC over this region is high, which could probably be a result of the gaps in the TOC time series. TOC minimum is observed during 2010 winter over region $\mathrm{B}$, which corresponds to eastern North American outflow. Negative change in TOC is observed over the region, which can be associated with the declining trend in TOC over the US as reported in earlier studies (Cooper et al., 2012, 2014; Parrish et al., 2012). The seasonal variation observed over regions $\mathrm{C}$ (southern Europe) becomes less pronounced between 2007 and 2009. The TOC change over the region is negative, which could probably be due to reduction of $\mathrm{O}_{3}$ precursor emissions. The region over Siberia (region D) shows significant negative change in TOC, which could probably be a result of response to emission reduction in $\mathrm{O}_{3}$ precursors and change in anthropogenic and biogenic halogens that are effective in $\mathrm{O}_{3}$ destruction (Parrish et al., 2012). In general, the observed significant negative change in TOC over the northern mid-latitude, particularly around Europe and North America (regions B, C and D), is a combination of changes in dynamics and chemical processes. The chemical processes involve the reduction in $\mathrm{O}_{3}$ precursor emissions and increase in anthropogenic and biogenic halogens that are effective in $\mathrm{O}_{3}$ destruction (Vestreng et al., 2009; Parrish et al., 2012). Synoptic-scale meteorological variability and dynamical modes including changes in tropospheric circulation indices such as those of the Arctic Oscillation (AO) and the NAO can play a role (Zhou et al., 2001; Chipperfield, 2003). A trend toward more equatorward planetary wave fluxes may also play a role in the negative change in tropospheric $\mathrm{O}_{3}$ in the northern mid-latitude (Kuroda and Kodera, 1999; Chen et al., 2005). Another important process that may be contributing to the decrease in tropospheric $\mathrm{O}_{3}$ in the northern mid-latitude is the decrease in the average total wave flux entering the stratosphere (Newman and Nash, 2000; Reid et al., 2000). Pronounced seasonal variation in TOC is observed over the regions of northern South America, southern South America, southern Africa, Southeast Asia and northern Australia outflow (regions E-I), with each region exhibiting significant change in TOC. Strong seasonal cycles in TOC are also observed over the Galapagos Islands (region J) and the southern Pacific Ocean (region K), with both regions showing insignificant negative change in TOC. The significant negative change in TOC observed over northern South America (region E) could be due to changes in humidity and solar actinic flux (Revell et al., 2015). The significant positive change in TOC observed over regions $\mathrm{F}$ and G (southern South America and central Africa) is primarily due to changes in pollution emission from biomass burning and anthropogenic activities (e.g. Fishman et al., 1991). The significant positive change in TOC over Southeast Asia (re- 
gion $\mathrm{H}$ ) could be associated with changes in anthropogenic emissions as well as changes in transport pattern as observed by many studies (e.g. Beig and Singh, 2007; Parrish et al., 2012). Changes in population and increased industrialization in eastern Asia have led to great changes in anthropogenic precursor emissions in this region. The observed significant positive TOC change over northern China (i.e. part of region $\mathrm{H}$ ) may be associated with high $\mathrm{O}_{3}$ over the northwestern mountainous areas during summer and in the afternoon hours (Tang et al., 2012). Over the northern Australia outflow (region I), a positive significant change in TOC is observed, which could probably be a result of changes in transport patterns and precursor emissions (Wai et al., 2014). Over the Galapagos Islands (region J), which are among the most renowned natural sites in the world with less impact of anthropogenic activities, an insignificant negative change in TOC is observed. The observed insignificant negative change in TOC in this region could be related to synoptic-scale meteorological variability. Over the southern Pacific Ocean (region $\mathrm{K}$ ), insignificant negative change in TOC is observed, which could be associated with the influence of photochemical reactions involving $\mathrm{OH}$ and $\mathrm{HO}_{2}$ radicals and changes in meteorology. A summary of the changes in TOCs as well as the mean values and standard deviations over the entire time series for the different regions is given in Table 2.

\section{Summary and conclusions}

In this study, changes in tropospheric $\mathrm{O}_{3}$ columns (TOCs) were derived from SCIAMACHY limb-nadir-matching (LNM) observations during the period 2003-2011 (Ebojie et al., 2014; Ebojie, 2014). TOC shows a statistically insignificant change at the $95 \%$ confidence level of $-0.2 \pm$ $0.4,0.3 \pm 0.4,0.1 \pm 0.5$ and $0.1 \pm 0.2 \% \mathrm{yr}^{-1}$ in the latitude bands $30-50^{\circ} \mathrm{N}, 20^{\circ} \mathrm{S}-0,0-20^{\circ} \mathrm{N}$ and $50-30^{\circ} \mathrm{S}$, respectively. From the global analysis of changes in TOC, positive changes significant at the $95 \%$ confidence level were observed over South Asia $\left(1-3 \% \mathrm{yr}^{-1}\right)$, the South American continent (up to $2 \% \mathrm{yr}^{-1}$ ), North America, especially around Alaska $\left(1-3 \% \mathrm{yr}^{-1}\right)$, the Australian outflow region (up to $2 \% \mathrm{yr}^{-1}$ ) as well as over some regions of the African continent (up to $2 \% \mathrm{yr}^{-1}$ ). The positive change in $\mathrm{O}_{3}$ over these regions may be attributed to changes in emissions of nitrogen oxides $\left(\mathrm{NO}_{x}\right)$ and other $\mathrm{O}_{3}$ precursors. In addition, changes in meteorology and intercontinental transport of $\mathrm{O}_{3}$ and its precursors might also have played a role in the observed changes in $\mathrm{O}_{3}$ over the regions. Significant increase in TOC is determined off the continents including Australia (up to $2 \% \mathrm{yr}^{-1}$ ), Eurasia $\left(1-3 \% \mathrm{yr}^{-1}\right.$ ) and South America (up to $3 \% \mathrm{yr}^{-1}$ ). The observed positive change in TOC over the oceanic regions may be associated with changes in dynamical processes such as advection, entrainment and transport of $\mathrm{O}_{3}$ and its precursors from the source regions. Significant negative TOC trends were observed over some re- gions of Europe and the North American continent (up to $-3 \% \mathrm{yr}^{-1}$ ), which may be attributed to reduction in $\mathrm{NO}_{x}$ and other tropospheric $\mathrm{O}_{3}$ precursor emissions over the regions. Halogen chemistry might have also contributed to the observed changes in tropospheric $\mathrm{O}_{3}$. Over the oceanic regions including the Pacific, Atlantic and Indian oceans, significant decreases in TOC $\left(-1\right.$ to $\left.-3 \% \mathrm{yr}^{-1}\right)$ were observed. The observed negative change in tropospheric $\mathrm{O}_{3}$ over these regions may be associated with the influence of photochemical reactions involving hydroxyl $(\mathrm{OH})$ and hydroperoxy $\left(\mathrm{HO}_{2}\right)$ radicals. Furthermore, changes in organic and inorganic halogens as well as changes in dissolved organic matter (DOM) photochemistry in surface waters could be an additional source of volatile organic compounds that have contributed to the destruction of $\mathrm{O}_{3}$. In general, changes in TOC in the observed period are smaller when compared with results obtained from studies on tropospheric $\mathrm{O}_{3}$ trends in the previous years (e.g. Marenco et al., 1994; Simmonds et al., 2004), probably due to the slowdown in the growth rate of $\mathrm{O}_{3}$ precursors as well as changes in the lowermost stratospheric $\mathrm{O}_{3}$ (WMO, 2011). The strengthening of legislation on air-pollution-related policies has contributed to the reduction of tropospheric $\mathrm{O}_{3}$ amounts and its precursor emissions. Changes in the tropopause altitude might have also contributed to the zonal or global change in tropospheric $\mathrm{O}_{3}$. During the period 2003-2011, extensive regions in the tropics and $\mathrm{NH}$ middle latitudes show significant responses to ENSO. The QBO response is only evident in some regions. Dynamical processes are mainly responsible for ENSO- and QBO-related TOC changes.

A final attribution of the variability and trends observed in specific regions to the different underlying processes is not possible based on this analysis. This task requires in addition dedicated model simulations that will allow us to separate the different relevant processes. The value of this study lies more in the presentation of experimental results on global, zonal and regional tropospheric ozone columns to be used as a benchmark for model simulations. In conclusion it can be stated that the results obtained in this paper provide first-hand information on tropospheric $\mathrm{O}_{3}$ changes globally.

Acknowledgements. We thank ESA and German Aerospace DLR for providing SCIAMACHY level 1 data for this study. This work was funded in part by the German Aerospace DLR SADOS (FKZ 50EE1105) project, by ESA through the SCIAMACHY Quality Working Group and Ozone_cci, by Ernst-Moritz-Arndt University of Greifswald, and the University and State of Bremen, Germany. The SCIAMACHY instrument, which flew on ESA's Envisat spacecraft, was supported by Germany, the Netherlands and Belgium.

The article processing charges for this open-access publication were covered by the University of Bremen.

Edited by: M. Dameris 


\section{References}

Appenzeller, C., Holton, J. R., and Rosenlof, K. H.: Seasonal variation of mass transport across the tropopause, J. Geophys. Res., 101, 15071-15078, doi:10.1029/96JD00821, 1996.

Baldwin, M. P., Gray, L. J., Dunkerton, T. J., Hamilton, K., Haynes, P. H., Randel, W. J., Holton, J. R., Alexander, M. J., Hirota, I., Horinouchi, T., Jones, D. B. A., Kinnersley, J. S., Marquardt, C., Sato, K., and Takahashi, M.: The quasi-biennial oscillation, Rev. Geophys., 39, 179-230, doi:10.1029/1999RG000073, 2001.

Beig, G. and Singh, V.: Trends in tropical tropospheric column ozone from satellite data and MOZART model, Geophys. Res. Lett., 34, L17801, doi:10.1029/2007GL030460, 2007.

Bell, C. J., Gray, L. J., Charlton-Perez, A. J., Joshi, M. M. and Scaife, A. A.: Stratospheric communication of El Niño teleconnections to European winter, J. Climate, 22, 4083-4096, doi:10.1175/2009JCLI2717.1, 2009.

Bjerknes, J.: A possible response of the atmospheric hadley circulation to equatorial anomalies of ocean temperature, Tellus, 18, 820-829, 1966.

Bramstedt, K., Noël, S., Bovensmann, H., Burrows, J. P., Lerot, C., Tilstra, L. G., Lichtenberg, G., Dehn, A., and Fehr, T.: SCIAMACHY Monitoring Factors: Observation and End-to-End Correction of Instrument Performance Degradation, in: Atmospheric Science Conference, SP-676, 7-11, Barcelona, Spain, September 2009.

Brasseur, G. P., Orlando, J. J., and Tyndall, G. S.: Atmospheric Chemistry and Global Change, Oxford Univ. Press, New York, 1999.

Brönnimann, S., Luterbacher, J., Staehelin, J., Svendby, T. M., Hansen, G. and Svenœ, T.: Extreme climate of the global troposphere and stratosphere in 1940-1942 related to El Niño, Nature, 431, 971-974, doi:10.1038/nature02982, 2004.

Bulic, I. and Kucharski, F.: Delayed ENSO impact on spring precipitation over the North/Atlantic European region, Clim. Dynam., 38, 2593-2612, 2012.

Butchart, N., Scaife, A. A., Austin, J., Hare, S. H. E., and Knight, J. R.: Quasi-biennial oscillation in ozone in a coupled chemistry-climate model, J. Geophys. Res., 108, 2156-2202, doi:10.1029/2002JD003004, 2003.

Butler, A. H., Polvani, M., and Deser, C.: Separating the stratospheric and tropospheric pathways of El Niño-Southern Oscillation teleconnections, Environ. Res. Lett., 9, 2, 024014 , doi:10.1088/1748-9326/9/2/024014, 2014.

Cagnazzo, C. and Manzini, E.: Impact of the stratosphere on the winter tropospheric teleconnections between ENSO and the North Atlantic and European region, J. Climate, 22, 1223-1238, 10.1175/2008JCLI2549.1, 2009.

Chandra, S., Ziemke, J. R., Min, W., and Read, W. G.: Effects of 1997-1998 El Niño on tropospheric ozone and water vapor, Geophys. Res. Lett., 25, 3867-3870, 1998.

Chandra, S., Ziemke, J. R., Bhartia, P. K., and Martin, R. V.: Tropical tropospheric ozone: implications for dynamics and biomass burning, J. Geophys. Res., 107, 4188, doi:10.1029/2001JD000447, 2002.

Chandra, S., Ziemke, J. R., and Martin, R. V.: Tropospheric ozone at tropical and middle latitudes derived from TOMS/MLS residual: comparison with a global model, J. Geophys. Res., 108, 4291, doi:10.1029/2002JD002912, 2003.
Chandra, S., Ziemke, J. R., Tie, X., and Brasseur, G.: Elevated ozone in the troposphere over the Atlantic and Pacific oceans in the Northern Hemisphere, Geophys. Res. Lett., 31, L23102, doi:10.1029/2004GL020821, 2004.

Chang, P., Ji, L., and Li, H.: A decadal climate variation in the tropical Atlantic Ocean from thermodynamic air-sea interactions, Nature, 385, 516-518, 1997.

Chen, W., Yang, S., and Huang, R. H.: Relationship between stationary planetary wave activity and the East Asian winter monsoon, J. Geophys. Res., 110, D14110, doi:10.1029/2004JD005669, 2005.

Chipperfield, M. P.: A three-dimensional model study of longterm mid-high latitude lower stratosphere ozone changes, Atmos. Chem. Phys., 3, 1253-1265, doi:10.5194/acp-3-1253-2003, 2003.

Coldewey-Egbers, M., Loyola R. D. G., Braesicke, P., Dameris, M., van Roozendael, M., Lerot, C., and Zimmer, W.: A new health check of the ozone layer at global and regional scales, Geophys. Res. Lett., 41, 1-10, doi:10.1002/2014GL060212, 2014.

Collimore, C. C., Martin, D. W., Hitchman, M. H., Huesmann, A., and Waliser, D. E.: On the relationship between the QBO and tropical deep convection, J. Climate, 16, 2552-2568, 2003.

Compo, G. P. and Sardeshmukh, P. D.: Removing ENSO-related variations from the climate record, J. Climate, 23, 1957-1978, 2010.

Cooper, O. R. and Parrish, D. D.: Air pollution export from and import to North America, in: Inter-Continental Transport of Air Pollution, edited by: Stohl, A., Springer, New York, 41-67, 4G, doi:10.1007/b94523, 2004.

Cooper, O. R., Gao, R. S., Tarasick, D., Leblanc, T., and Sweeney, J.: Long-term ozone trends at rural ozone monitoring sites across the United States, 1990-2010, J. Geophys. Res., 117, D22307, doi:10.1029/2012JD018261, 2012.

Cooper, O. R., Parrish, D. D., Ziemke, J., Balashov, N. V., Cupeiro, M., Galbally, I. E., Gilge, S., Horowitz, L., Jensen, N. R., Lamarque, J.-F., Naik, V., Oltmans, S. J., Schwab, J., Shindell, D. T., Thompson, A. M., Thouret, V., Wang, Y., and Zbinden, R. M.: Global distribution and trends of tropospheric ozone: an observation-based review, Elementa: Science of the Anthropocene, 2, 000029, doi:10.12952/journal.elementa.000029, 2014.

Crutzen, P. J.: The role of $\mathrm{NO}$ and $\mathrm{NO}_{2}$ in the chemistry of the troposphere and stratosphere, Annu. Rev. Earth Pl. Sc., 7, 443472, 1979.

Danielsen, E. F.: Stratospheric-tropospheric exchange based on radioactivity, ozone and potential vorticity, J. Atmos. Sci., 25, 502 518,1968

de Laat, A. T. J., Aben, I., and Roelofs, G. J.: A model perspective on total tropospheric $\mathrm{O}_{3}$ column variability and implications for satellite observations, J. Geophys. Res., 110, D13303, doi:10.1029/2004JD005264, 2005.

Dentener, F., Stevenson, D., Cofala, J., Mechler, R., Amann, M., Bergamaschi, P., Raes, F., and Derwent, R.: The impact of air pollutant and methane emission controls on tropospheric ozone and radiative forcing: CTM calculations for the period 19902030, Atmos. Chem. Phys., 5, 1731-1755, doi:10.5194/acp-51731-2005, 2005.

Derwent, R., Simmonds, P., Seuring, S., and Dimmer, C.: Observation and interpretation of the seasonal cycles in the surface con- 
centrations of ozone and carbon monoxide at Mace Head, Ireland from 1990 to 1994, Atmos. Environ., 32, 145-157, 1998.

Derwent, R. G., Jenkin, M. E., Saunders, S. M., Pilling, M. J., Simmonds, P. G., Passant, N. R., Dollard, G. J., Dumitrean, P., and Kent, A.: A photochemical ozone formation in north west Europe and its control, Atmos. Environ., 37, 1983-1991, 2003.

Dickerson, R. R., Doddridge, B. G., Kelley, P. K., and Rhoads, K. P.: Large-scale pollution of the atmosphere over the North Atlantic Ocean: evidence from Bermuda, J. Geophys. Res., 100, 89458952, 1995.

Dickerson, R. R., Rhoads, K. P., Carsey, T. P., Oltmans, S. J., Burrows, J. P., and Crutzen, P. J.: Ozone in the remote marine boundary layer: a possible role for halogens, J. Geophys. Res., 104, 21385-21395, 1999.

Doughty, D. C., Thompson, A. M., Schoeberl, M. R., Stajner, I., Wargan, K., and Hui, W. C. J.: An intercomparison of tropospheric ozone retrievals derived from two Aura instruments and measurements in western North America in 2006, J. Geophys. Res., 116, D06303,doi:10.1029/2010JD014703, 2011.

Duncan, B. N., Yoshida, Y., Olson, J. R., Sillman, S., Martin, R. V., Lamsal, L., Hu, Y., Pickering, K. E., Retscher, C., Allen, D. J., and Crawford, J. H.: Application of OMI observations to a spacebased indicator of $\mathrm{NO}_{x}$ and VOC controls on surface ozone formation, Atmos. Environ., 44, 2213-2223, 2010.

Ebojie, F.: Tropospheric ozone columns retrieval from SCIAMACHY limb-nadir-matching observations (PhD dissertation), Universität Bremen: Physik/Elektrotechnik, available at: elib. suub.uni-bremen.de/edocs/00104050-1.pdf (last access: 15 December 2015), 2014.

Ebojie, F., von Savigny, C., Ladstätter-Weißenmayer, A., Rozanov, A., Weber, M., Eichmann, K.-U., Bötel, S., Rahpoe, N., Bovensmann, H., and Burrows, J. P.: Tropospheric column amount of ozone retrieved from SCIAMACHY limb-nadir-matching observations, Atmos. Meas. Tech., 7, 2073-2096, doi:10.5194/amt-72073-2014, 2014.

Eckert, E., von Clarmann, T., Kiefer, M., Stiller, G. P., Lossow, S., Glatthor, N., Degenstein, D. A., Froidevaux, L., GodinBeekmann, S., Leblanc, T., McDermid, S., Pastel, M., Steinbrecht, W., Swart, D. P. J., Walker, K. A., and Bernath, P. F.: Drift-corrected trends and periodic variations in MIPAS IMK/IAA ozone measurements, Atmos. Chem. Phys., 14, 25712589, doi:10.5194/acp-14-2571-2014, 2014.

Edwards, D. P., Emmons, L. K., Gille, J. C., Chu, A., Attie, J.-L., Giglio, L., Wood, S. W., Haywood, J., Deeter, M. N., Massie, S. T., Ziskin, D. C., and Drummond, J. R.: Satellite observed pollution from Southern Hemisphere biomass burning, J. Geophys. Res., 111, D14312, doi:10.1029/2005JD006655, 2006.

Finlayson-Pitts, B. J., Livingston, F. E., and Pitts Jr., J. N.: Ozone destruction and bromine photochemistry at ground level in the Arctic spring, Nature, 343, 622-625, doi:10.1038/343622a0, 1990.

Fiore, A. M., Dentener, F. J., Wild, O., Cuvelier, C., Schultz, M. G., Hess, P., Textor, C., Schulz, M., Doherty, R. M., Horowitz, L. W., MacKenzie, I. A., Sanderson, M. G., Shindell, D. T., Stevenson, D. S., Szopa, S., Van Dingenen, R., Zeng, G., Atherton, C., Bergmann, D., Bey, I., Carmichael, G., Collins, W. J., Duncan, B. N., Faluvegi, G., Folberth, G., Gauss, M., Gong, S., Hauglustaine, D., Holloway, T., Isaksen, I. S. A., Jacob, D. J., Jonson, J. E., Kaminski, J. W., Keating, T. J., Lupu, A., Marmer,
E., Montanaro, V., Park, R. J., Pitari, G., Pringle, K. J., Pyle, J. A., Schroeder, S., Vivanco, M. G., Wind, P., Wojcik, G., Wu, S., and Zuber, A.: Multimodel estimates of intercontinental sourcereceptor relationships for ozone pollution, J. Geophys. Res., 114, D04301, doi:10.1029/2008JD010816, 2009.

Fishman, J., Watson, C., Larsen, J., and Logan, J.: Distribution of tropospheric ozone determined from satellite data, J. Geophys. Res., 95, 3599-3617, 1990.

Fishman, J., Fakhruzzaman, K., Cros, B., and Nganda, D.: Identification of widespread pollution in the Southern Hemisphere deduced from satellite analyses, Science, 252, 5013, 1693-1696, doi:10.1126/science.252.5013.1693, 1991.

Fujiwara, M., Kita, K., Kawakami, S., Ogawa, T., Komala, N., Saraspriya, S., and Suripto, A.: Tropospheric ozone enhancements during the Indonesian forest fire events in 1994 and in 1997 as revealed by ground-based observations, Geophys. Res. Lett., 26, 2417-2420, 1999.

Fusco, A. C. and Logan, J. A.: Analysis of 1970-1995 trends in tropospheric ozone at Northern Hemisphere midlatitudes with the GEOS-CHEM model, J. Geophys. Res., 108, 4449, doi:10.1029/2002JD002742, 2003.

Garfinkel, C. I. and Hartmann, D. L.: The influence of the quasibiennial oscillation on the troposphere in winter in a hierarchy of models, Part I: simplified dry GCMS, J. Atmos. Sci., 68, 12731289, doi:10.1175/2011JAS3665.1, 2011.

Gebhardt, C., Rozanov, A., Hommel, R., Weber, M., Bovensmann, H., Burrows, J. P., Degenstein, D., Froidevaux, L., and Thompson, A. M.: Stratospheric ozone trends and variability as seen by SCIAMACHY from 2002 to 2012, Atmos. Chem. Phys., 14, 831-846, doi:10.5194/acp-14-831-2014, 2014.

Gentner, D. R., Ormeño, E., Fares, S., Ford, T. B., Weber, R., Park, J.-H., Brioude, J., Angevine, W. M., Karlik, J. F., and Goldstein, A. H.: Emissions of terpenoids, benzenoids, and other biogenic gas-phase organic compounds from agricultural crops and their potential implications for air quality, Atmos. Chem. Phys., 14, 5393-5413, doi:10.5194/acp-14-5393-2014, 2014.

Graf, H. F. and Zanchettin, D.: Central Pacific El Niño, the subtropical bridge, and Eurasian clim., J. Geophys. Res., 117, D01102, doi:10.1029/2011JD016493, 2012.

Guenther, A., Geron, C., Pierce, T., Lamb, B., Harley, P., and Fall, R.: Natural emissions of non-methane volatile organic compounds; carbon monoxide, and oxides of nitrogen from North America, Atmos. Environ., 34, 2205-2230, 2000.

Haigh, J. D., Blackburn, M., and Day, R.: The response of tropospheric circulation to perturbations in lower-stratospheric temperature, J. Climate, 18, 3672-3685, doi:10.1175/JCLI3472.1, 2005.

Handorf, K. and Dethloff, K.: Atmospheric teleconnections and flow regimes under future climate projections, Eur. Phys. J. Special Topics, 174, 237-255, doi:10.1140/epjst/e2009-01104-9, 2009.

Hao, J. and Wang, L.: Chemistry and physiology of Los Angeles smog, Ind. Eng. Chem., 44, 1342-1346, 1952.

Hastenrath, S.: On the upper-air circulation over the equatorial Americas, Arch. Meteor. Geophys. Bioklimatol., Ser. A, 25, 309-321, 1977.

Horel, J. D. and Wallace, J. M.: Planetary-scale atmospheric phenomena associated with the Southern Oscillation, Mon. Weather Rev. 109, 813-829, doi:10.1175/1520-0493, 1981. 
Hoerling, M. P., Kumar, A., and Zhong, M.: El Niño, La Niña, and the nonlinearity of their teleconnections, J. Climate, 10, 17691786, doi:10.1175/1520-0442, 1997.

Holton, J. R. and Tan, H. C.: The influence of the equatorial QBO in the global circulation at $50 \mathrm{mb}$, J. Atmos. Sci., 37, 2200-2208, 1980.

Hudson, R. D.: Measurements of the movement of the jet streams at mid-latitudes, in the Northern and Southern Hemispheres, 1979 to 2010, Atmos. Chem. Phys., 12, 7797-7808, doi:10.5194/acp12-7797-2012, 2012.

Ineson, S., and Scaife, A. A.: The role of the stratosphere in the European climate response to El Niño, Nat. Geosci., 2, 32-36, doi:10.1038/ngeo381, 2009.

Jacob, D. J. and Winner, D. A.: Effect of climate change on air quality, Atmos. Environ., 43, 51-63, doi:10.1016/j.atmosenv.2008.09.051, 2009.

Jacob, D. J., Logan, J. A., and Murti, P. P.: Effect of rising Asian emissions on surface ozone in the United States, Geophys. Res. Lett., 26, 2175-2178, 1999.

Jacobson, M. Z.: Air Pollution and Global Warming: History, Science, and Solutions, 2nd Edn., Cambridge Univ. Press, Cambridge, 2012.

Jaffe, D. A., Anderson, T., Covert, D., Kotchenruther, R., Trost, B., Danielson, J., Simpson, W., Bertsen, T., Karlsdottir, S., Blake, D., Harris, J., Carmichael, G., and Uno, I.: Transport of Asian air pollution to North America, Geophys. Res. Lett., 26, 711-714, 1999.

Kim, J. H. and Newchurch, M. J.: Climatology and trends of tropospheric ozone over the eastern Pacific Ocean: The influences of biomass burning and tropospheric dynamics, Geophys. Res. Lett., 23, 3723-3726, doi:10.1029/96GL03615, 1996.

Kley, D., Smit, H. G. J., Vómel, H., Grassl, H., Ramanathan, V., Crutzen, P. J., Williams, S. J. M., and Oltmans, S.: Tropospheric water vapour and ozone cross-sections in a zonal plane over the central equatorial Pacific, Q. J. Roy. Meteor. Soc., 123, 20092040, 1997.

Kuroda, Y. and Kodera, K.: Role of planetary waves in the stratosphere-troposphere coupled variability in the Northern Hemisphere winter, Geophys. Res. Lett., 26, 2375-2378, 1999.

Ladstädter-Weissenmayer, A., Burrows, J. P., Crutzen, P. J., and Richter, A.: GOME: Biomass burning and its influence on the troposphere, in: European Symposium on Atmospheric Measurements from Space, ESA WPP-161, ESA/ESTEC, Noordwijk, The Netherlands, 369-374, 1999.

Lamarque, J. F. and Hess, P. G.: Cross-tropopause mass exchange and potential vorticity budget in a simulated tropopause folding., J. Atmos. Sci., 51, 2246-2269, 1994.

Lee, S., Shelow, D. M., Thompson, A. M., and Miller, S. K.: QBO and ENSO variability in temperature and ozone from SHADOZ, 1998-2005, J. Geophys. Res., 115, D18105, doi:10.1029/2009JD013320, 2010.

Lelieveld, J. and Dentener, F. J.: What controls tropospheric ozone?, J. Geophys. Res., 105, 3531-3551, doi:10.1029/1999JD901011, 2000.

Lelieveld, J., van Aardenne, J., Fischer, H., de Reus, M., Williams, J., and Winkler, P.: Increasing ozone over the Atlantic Ocean, Science, 304, 1483-1487, 2004.

Levy, H. I.: Normal atmosphere: large radical and formaldehyde concentrations predicted, Science, 173, 141-143, 1971.
Lin, M., Horowitz, L. W., Oltmans, S. J. Fiore, A. M., and Fan, S.: Tropospheric ozone trends at Manna Loa Observatory tied to decadal climate variability, Nat. Geosci., 7, 136-143, 2014.

Lippmann, M.: Health-effects of tropospheric ozone, Environ. Sci. Technol., 25, 1954-1962, 1991.

Liu, H., Jacob, D. J., Chan, L. Y., Oltmans, S. J., Bey, I., Yantosca, R. M., Harris, J. M., Duncan, B. N., and Martin, R. V.: Sources of tropospheric ozone along the Asian Pacific Rim: an analysis of ozonesonde observations, J. Geophys. Res., 107, 4573, doi:10.1029/2001JD002005, 2002.

Logan, J. A., Prather, M. J., Wofsy, S. C., and McElroy, M. B.: Tropospheric chemistry: a global perspective, J. Geophys. Res., 86, 7210-7255, 1981

Logan, J. A., Staehelin, J., Megretskaia, I. A., Cammas, J.-P., Thouret, V., Claude, H., De Backer, H., Steinbacher, M., Scheel, H.-E., Stübi, R., Fröhlich, M., and Derwent, R.: Changes in ozone over Europe: analysis of ozone measurements from sondes, regular aircraft (MOZAIC) and alpine surface sites, J. Geophys. Res., 117, D09301, doi:10.1029/2011JD016952, 2012.

Marenco, A., Gouget, H., Nédélec, P., Pagés, J. P., and Karcher, F.: Evidence of a long-term increase in tropospheric ozone from Pic du Midi data series: consequences: positive radiative forcing, J. Geophys. Res., 99, 16617-16632, 1994.

Milford, J. B., Russell, A. G., and McRae, G. J.: A new approach to photochemical pollution control: implications of spatial patterns in pollutant responses to reductions in nitrogen oxides and reactive organic gas emissions, Environ. Sci. Technol., 23, 12901301, 1989.

Monks, P. S.: Gas-phase radical chemistry in the troposphere, Chem. Soc. Rev., 34, 376-395, doi:10.1039/B307982C, 2005.

Moxim, W. J. and Levy II, H.: A model analysis of the tropical South Atlantic Ocean tropospheric ozone maximum: The interaction of transport and chemistry, J. Geophys. Res., 105, 1739317415,2000

Naja, M., Akimoto, H., and Staehelin, J.: Ozone in background and photochemically aged air over central Europe: Analysis of longterm ozonesonde data from Hohenpeissenberg and Payerne, J. Geophys. Res., 108, 4063, doi:10.1029/2002JD002477, 2003.

Neu, J. L., Flury, T., Manney, G. L., Santee, M. L., Livesey, N. J., and Worden, J.: Tropospheric ozone variations governed by changes in stratospheric circulation, Nat. Geosci., 7, 340-344, doi:10.1038/ngeo2138, 2014.

Newman, P. A. and Nash, E. R.: Quantifying the wave driving of the stratosphere, J. Geophys. Res., 105, 12485-12497, 2000.

Oltmans, S. J., Lefohn, A. S., Harris, J. M., Galbally, I., Scheel, H. E., Bodeker, G., Brunke, E., Claude, H., Tarasick, D. W., Johnson, B. J., Simmonds, P., Shadwick, D., Anlauf, K., Hayden, K., Schmidlin, F., Fujimoto, T., Akagi, K., Meyer, C., Nichol, S., Davies, J., Redondas, A., and Cuevas, E.: Long-term changes in tropospheric ozone, Atmos. Environ., 40, 3156-3173, doi:10.1029/2008JD010378, 2006.

Oltmans, S. J., Lefohn, A. S., Harris, J. M., Tarasick, D. W., Thompson, A. M., Wernli, H., Johnson, B. J., Davies, J., Novelli, P., Montzka, S., Sweeney, C., Patrick, L. C., Jefferson, A., Dann, T., Ray, J. D., Shapiro, M., and Holben, B. N.: Enhanced ozone over western North America from biomass burning in Eurasia during April 2008 as seen in surface and profile observations, Atmos. Environ., 44, 4497-4509, 10.1016/j.atmosenv.2010.07.004, 2010 . 
Oltmans, S. J., Lefohn, A. S., Shadwick, D., Harris, J. M., Scheel, H. E., Galbally, I., Tarasick, D. W., Johnson, B. J., Brunke, E. G., Claude, H., Zeng, G., Nichol, S., Schmidlin, F., Davies, J., Cuevas, E., Redondas, A., Naoe, H., Nakano, T., and Kawasato, T.: Recent tropospheric ozone changes - A pattern dominated by slow or no growth, Atmos. Environ., 67, 331-351, doi: 10.1016/j.atmosenv.2012.10.057, 2013.

Oman, L. D., Douglass, A. R., Ziemke, J. R., Rodriguez, J. M., Waugh, D. W., and Nielsen, J. E.: The ozone response to ENSO in Aura satellite measurements and a chemistry-climate simulation, J. Geophys. Res.-Atmos., 118, 965-976, 2013.

Parrish, D. D., Holloway, J. S., Trainer, M., Murphy, P. C., Forbes, G. L., and Fehsenfeld, F. C.: Export of North American ozone pollution to the North Atlantic Ocean, Science, 259, 1436-1439, 1993.

Parrish, D. D., Law, K. S., Staehelin, J., Derwent, R., Cooper, O. R., Tanimoto, H., Volz-Thomas, A., Gilge, S., Scheel, H.-E., Steinbacher, M., and Chan, E.: Long-term changes in lower tropospheric baseline ozone concentrations at northern mid-latitudes, Atmos. Chem. Phys., 12, 11485-11504, doi:10.5194/acp-1211485-2012, 2012.

Parrish, D. D., Law, K. S., Staehelin, J., Derwent, R., Cooper, O. R., Tanimoto, H., Volz-Thomas, A., Gilge, S., Scheel, H. E., Steinbacher, M., and Chan, E.: Lower tropospheric ozone at northern midlatitudes: changing seasonal cycle, Geophys. Res. Lett., 40, 1631-1636, doi:10.1002/grl.50303, 2013.

Parrish, D. D., Lamarque, J.-F., Naik, V., Horowitz, L., Shindell, D. T., Staehelin, J., Derwent, R., Cooper, O. R., Tanimoto, H., Volz-Thomas, A., Gilge, S., Scheel, H.-E., Steinbacher, M., and Fröhlich, M.: Long-term changes in lower tropospheric baseline ozone concentrations: comparing chemistry-climate models and observations at northern midlatitudes, J. Geophys. Res.-Atmos., 119, 5719-5736, doi:10.1002/2013JD021435, 2014.

Pascoe, C. L., Gray, L. J., Crooks, S. A., Juckes, M. N., and Baldwin, M. P.: The quasi-biennial oscillation: analysis using ERA-40 data, J. Geophys. Res., 110, D08105, doi:10.1029/2004JD004941, 1948.

Pfister, G. G., Emmons, L. K., Hess, P. G., Lamarque, J.-F., Thompson, A. M., and Yorks, J. E.: Analysis of the Summer 2004 ozone budget over the United States using Intercontinental Transport Experiment Ozonesonde Network Study (IONS) observations and Model of Ozone and Related Tracers (MOZART-4) simulations, J. Geophys. Res., 113, D23306, doi:10.1029/2008JD010190, 2008.

Pike, A. C.: Intertropical convergence zone studies with an interacting atmosphere and ocean model, Mon. Weather Rev., 99, 469477, 1971.

Randel, W. and Thompson, A.: Interannual variability and trends in tropical ozone derived from SAGE II satellite data and SHADOZ ozonesondes, J. Geophys. Res., 116, D07303, doi:10.1029/2010JD015195, 2011.

Randel, W. J., Wu, F., Swinbank, Nash, R., and O'Neill, A.: Global QBO circulation derived from UKMO stratospheric analyses, J. Atmos. Sci., 56, 457-474, 1999.

Read, K. A., Mahajan, A. S., Carpenter, L. J., Evans, M. J., Faria, B. V. E., Heard, D. E., Hopkins, J. R., Lee, J. D., Moller, S. J., Lewis, A. C., Mendes, L., McQuaid, J. B., Oetjen, H., Saiz-Lopez, A., Pilling, M. J., and Plane, J. M. C.: Ex- tensive halogen-mediated ozone destruction over the tropical Atlantic Ocean, Nature, 453, 1232-1235, 2008.

Reichler, T., Kushner, P. J., and Polvani, L. M.: The Coupled Stratosphere-Troposphere Response to Impulsive Forcing from the Troposphere, J. Atmos. Sci., 62, 3337-3352, doi:10.1175/JAS3527.1, 2005. Reichler, T., Kushner, P. J., and Polvani, L. M.: The Coupled Stratosphere-Troposphere Response to Impulsive Forcing from the Troposphere, J. Atmos. Sci., 62, 3337-3352, doi:10.1175/JAS3527.1, 2005.

Reid, S. J., Tuck, A. F., and Kildaris, G.: On the changing abundance of ozone minima at Northern midlatitudes, J. Geophys. Res., 105, 12169-12180, 2000.

Revell, L. E., Tummon, F., Stenke, A., Sukhodolov, T., Coulon, A., Rozanov, E., Garny, H., Grewe, V., and Peter, T.: Drivers of the tropospheric ozone budget throughout the 21 st century under the medium-high climate scenario RCP 6.0, Atmos. Chem. Phys., 15, 5887-5902, doi:10.5194/acp-15-5887-2015, 2015.

Romanski, J., Romanou, A. Bauer, M., and Tselioudis, G.: Teleconnections, midlatitude cyclones and Aegean Sea turbulent heat flux variability on daily through decadal time scales, Reg. Environ. Change, 14, 1713-1723, doi:10.1007/s10113-013-0545-0, 2014.

Sauvage, B., Thouret, V., Cammas, J.-P., Gheusi, F., Athier, G., and Nédélec, P.: Tropospheric ozone over Equatorial Africa: regional aspects from the MOZAIC data, Atmos. Chem. Phys., 5, 311335, doi:10.5194/acp-5-311-2005, 2005.

Sauvage, B., Thouret, V., Thompson, A. M., Witte, J. C., Cammas, J. P., Nédélec, P., and Athier, G.: Enhanced view of the tropical Atlantic ozone paradox and zonal wave one from the in situ MOZAIC and SHADOZ data, J. Geophys. Res., 111, D01301, doi:10.1029/2005JD006241, 2006.

Sauvage, B., Gheusi, F., Thouret, V., Cammas, J.-P., Duron, J., Escobar, J., Mari, C., Mascart, P., and Pont, V.: Medium-range midtropospheric transport of ozone and precursors over Africa: two numerical case studies in dry and wet seasons, Atmos. Chem. Phys., 7, 5357-5370, doi:10.5194/acp-7-5357-2007, 2007a.

Sauvage, B., Martin, R. V., van Donkelaar, A., and Ziemke, J. R.: Quantification of the factors controlling tropical tropospheric ozone and the South Atlantic maximum, J. Geophys. Res., 112, D11309, doi:10.1029/2006JD008008, 2007b.

Scaife, A. A., Arribas, A., Blockley, E., Brookshaw, A., Clark, R. T., Dunstone, N., Eade, R., Fereday, D., Folland, C. K., Gordon, M., Hermanson, L., Knight, J. R., Lea, D. J., MacLachlan, C., Maidens, A., Martin, M., Peterson, A. K., Smith, D., Vellinga, M., Wallace, E., Waters, J., and Williams, A.: Skillful long-range prediction of European and North American winters, Geophys. Res. Lett., 41, 2514-2519, doi:10.1002/2014gl059637, 2014.

Schneider, T., Bischoff, T., and Haug, G. H.: Migrations and dynamics of the intertropical convergence zone, Nature, 513, 4553, doi:10.1038/nature13636, 2014.

Schultz, M. G., Jacob, D. J., Wang, Y., Logan, J. A., Atlas, E. L., Blake, D. R., Blake, N. J., Bradshaw, J. D., Browell, E. V., Fenn, M. A., Flocke, F., Gregory, G. L., Heikes, B. G., Sachse, G. W., Sandholm, S. T., Shetter, R. E., Singh, H. B., and Talbot, R. W.: On the origin of tropospheric ozone and $\mathrm{NO}_{x}$ over the tropical South Pacific, J. Geophys. Res., 104, 5829-5843, doi:10.1029/98JD02309, 1999.

Shindell, D. T., Faluvegi, G., Lacis, A., Hansen, J., Ruedy, R., and Aguilar, E.: Role of tropospheric ozone increases in 
20th-century climate change, J. Geophys. Res., 111, D08302, doi:10.1029/2005JD006348, 2006.

Sillman, S., Logan, J. A., and Wofsy, S. C.: The sensitivity of ozone to nitrogen oxides and hydrocarbons in regional ozone episodes, J. Geophys. Res., 95, 1837-1851, doi:10.1029/JD095iD02p01837, 1990.

Simmonds, P. G., Derwent, R. G., Manning, A. L., and Spain, G.: Significant growth in surface ozone at Mace Head, Ireland, 1987-2003, Atmos. Environ., 38, 4769-4778, 2004.

Simpson, I. R., Shepherd, T. G., and Sigmond, M.: Dynamics of the lower stratospheric circulation response to ENSO, J. Atmos. Sci., 68, 2537-2556, 2011.

Stiller, G. P., von Clarmann, T., Haenel, F., Funke, B., Glatthor, N., Grabowski, U., Kellmann, S., Kiefer, M., Linden, A., Lossow, S., and López-Puertas, M.: Observed temporal evolution of global mean age of stratospheric air for the 2002 to 2010 period, Atmos. Chem. Phys., 12, 3311-3331, doi:10.5194/acp-12-33112012, 2012.

Stohl, A., Forster, C., Huntrieser, H., Mannstein, H., McMillan, W. W., Petzold, A., Schlager, H., and Weinzierl, B.: Aircraft measurements over Europe of an air pollution plume from Southeast Asia - aerosol and chemical characterization, Atmos. Chem. Phys., 7, 913-937, doi:10.5194/acp-7-913-2007, 2007.

Tang, G., Wang, Y., Li, X., Ji, D., Hsu, S., and Gao, X.: Spatialtemporal variations in surface ozone in Northern China as observed during 2009-2010 and possible implications for future air quality control strategies, Atmos. Chem. Phys., 12, 2757-2776, doi:10.5194/acp-12-2757-2012, 2012.

Thompson, A. M., Doddridge, B. G., Witte, J. C., Hudson, R. D., Luke, W. T., Johnson, J. E., Johnson, B. J., Oltmans, S. J., and Weller, R.: A tropical Atlantic paradox: shipboard and satellite views of a tropospheric ozone maximum and wave-one in January-February 1999, Geophys. Res. Lett., 27, 3317-3320, 2000

Thompson, A. M., Witte, J. C., Hudson, R. D., Guo, H., Herman, J. R., and Fujiwara, M.: Tropical tropospheric ozone and biomass burning, Science, 291, 2128-2132, 2001.

Thompson, A. M., Yorks, J. E., Miller, S. K., Witte, J. C., Dougherty, K. M., Morris, G. A., Baumgardner, D., Ladino, L., and Rappenglück, B.: Tropospheric ozone sources and wave activity over Mexico City and Houston during MILAGRO/Intercontinental Transport Experiment (INTEX-B) Ozonesonde Network Study, 2006 (IONS-06), Atmos. Chem. Phys., 8, 5113-5125, doi:10.5194/acp-8-5113-2008, 2008.

Thompson, A. M., Balashov, N. V., Witte, J. C., Coetzee, J. G. R., Thouret, V., and Posny, F.: Tropospheric ozone increases over the southern Africa region: bellwether for rapid growth in Southern Hemisphere pollution?, Atmos. Chem. Phys., 14, 9855-9869, doi:10.5194/acp-14-9855-2014, 2014.

Tiao, G. C., Reinsel, G. C., Xu, D., Pedrick, J. H., Zhu, X., Miller, A. J., DeLuisi, J. J., Mateer, C. L., and Wuebbles, D. J.: Effects of autocorrelation and temporal sampling schemes on estimates of trend and spatial correlation, J. Geophys. Res., 95, 20507-20517, 1990.

TOR-2: Tropspheric Ozone Research, Eurotrac-2 Subproject Final Report, ISS GSF-National Research Center for Environment and Health, Munich, Germany, 2003.

Trenberth, K. E., Branstator, G. W., Karoly, D., Kumar, A., Lau, N. C., and Ropelewski, C.: Progress during TOGA in un- derstanding and modeling global teleconnections associated with tropical sea surface temperatures, J. Geophys. Res., 103, 1429114324, doi:10.1029/97JC01444, 1998.

Trenberth, K. E., Stepaniak, D. P., and Caron, J. M.: The global monsoon as seen through the divergent atmospheric circulation, J. Climate, 13, 3969-3993, 2000.

Trenberth, K. E., Caron, J. M., Stepaniak, D. P., and Worley, S.: Evolution of El Niño-Southern Oscillation and global atmospheric surface temperatures, J. Geophys. Res., 107 (D8), doi:10.1029/2000JD000298, 2002.

Valks, P., Hao, N., Gimeno Garcia, S., Loyola, D., Dameris, M., Jöckel, P., and Delcloo, A.: Tropical tropospheric ozone column retrieval for GOME-2, Atmos. Meas. Tech., 7, 2513-2530, doi:10.5194/amt-7-2513-2014, 2014.

Vestreng, V., Ntziachristos, L., Semb, A., Reis, S., Isaksen, I. S. A., and Tarrasón, L.: Evolution of $\mathrm{NO}_{\mathrm{x}}$ emissions in Europe with focus on road transport control measures, Atmos. Chem. Phys., 9, 1503-1520, doi:10.5194/acp-9-1503-2009, 2009.

von Clarmann, T., Stiller, G., Grabowski, U., Eckert, E., and Orphal, J.: Technical Note: Trend estimation from irregularly sampled, correlated data, Atmos. Chem. Phys., 10, 6737-6747, doi:10.5194/acp-10-6737-2010, 2010.

von Glasow, R., Sander, R., Bott, A., and Crutzen, P. J.: Modelling halogen chemistry in the marine boundary layer, 1. Cloud-free MBL, J. Geophys. Res., 107, 4341-4356, 2002.

Wai, K. M., Wu, S., Kumar, A., and Liao, H.: Seasonal variability and long-term evolution of tropospheric composition in the tropics and Southern Hemisphere, Atmos. Chem. Phys., 14, 48594874, doi:10.5194/acp-14-4859-2014, 2014.

Wang, C.: ENSO, Atlantic climate variability, and the Walker and Hadley circulations. in: The Hadley Circulation: Present, Past, and Future, edited by: Diaz, H. F. and Bradley, R. S., Kluwer Academic Publishers, 173-202, 2005.

Weatherhead, E. C., Reinsel, G. C., Tiao, G. C., Jackman, C. H., Bishop, L., Frith, S. M. H., DeLuisi, J., Keller, T., Oltmans, S. J., Fleming, E. L., Wuebbles, D. J., Kerr, J. B., Miller, A. J., Herman, J., McPeters, R., Nagatani, R. M., and Frederick, J. E.: Detecting the recovery of total column ozone, J. Geophys. Res., 105, 22201-22210, doi:10.1029/2000JD900063, 2000.

Wild, O. and Akimoto, H.: Intercontinental transport of ozone and its precursors in a three-dimensional global CTM, J. Geophys. Res., 106, 27729-27744, doi:10.1029/2000JD000123, 2001.

WMO: World Meteorological Organization, Scientific Assessment of Ozone Depletion: 1998, Global Ozone Research and Monitoring Project-Report No. 44, Geneva, WMO 44, Geneva, Switzerland, 1999.

WMO (World Meteorological Organization), Scientific Assessment of Ozone Depletion: 2010, Global Ozone Research and Monitoring Project-Report No. 52, 516 pp., Geneva, Switzerland, 2011.

Wu, L., Su, H., and Jiang, J. H.: Regional simulations of deep convection and biomass burning over South America: 1. Model evaluations using multiple satellite data sets, J. Geophys. Res., 116, D17208, doi:10.1029/2011JD016105, 2011.

Xie, S. P. and Philander, S. G. H: A coupled ocean-atmosphere model of relevance to the ITCZ in the eastern Pacific, Tellus, 46A, 340-350, 1994.

Xie, S. P. and Tanimoto, Y.: A pan-Atlantic decadal climate oscillation, Geophys. Res. Lett., 25, 2185-2188, 1998. 
Ye, D. Z. and Wu, G.: The role of the heat source of the Tibetan Plateau in the general circulations, Meteorol. Atmos. Phys., 67, 181-198, doi:10.1007/BF01277509, 1998.

Zeng, G. and Pyle, J. A.: Influence of El Niño Southern Oscillation on stratosphere/troposphere exchange and the global ozone budget, Geophys. Res. Lett., 32, L01814, doi:10.1029/2004GL021353, 2005.

Zhang, J., Rao, S. T., and Daggupaty, S. M.: Meteorological processes and ozone exceedances in the northeastern United States during the 12-16 July 1995 episode, J. Appl. Meteorol., 37, 776789, 1998.

Zhang, P., Yang, S., and Kousky, W. E.: South Asian High and Asian-Pacific-American climate teleconnection, Adv. Atmos. Sci., 22, 915-923, doi:10.1007/BF02918690, 2005.

Zhou, S., Miller, A. J., Wang, J., and Angell, J.: Trends of NAO and $\mathrm{AO}$ and their associations with stratospheric processes, Geophys. Res. Lett., 28, 4107-4110, 2001.
Ziemke, J. R., Chandra, S., and Bhartia, P. K.: A 25-year data record of atmospheric ozone in the Pacific from Total Ozone Mapping Spectrometer (TOMS) cloud slicing: implications for ozone trends in the stratosphere and troposphere, J. Geophys. Res., 110, D15105, doi:10.1029/2004JD005687, 2005.

Ziemke, J. R., Olsen, M. A., Witte, J. C., Douglass, A. R., Strahan, S. E., Wargan, K., Liu, X., Schoeberl, M. R., Yang, K., Kaplan, T. B., Pawson, S., Duncan, B. N., Newman, P. A., Bhartia, P. K., and Heney, M. K.: Assessment and applications of NASA ozone data products derived from Aura OMI/MLS satellite measurements in context of the GMI chemical transport model, J. Geophys. Res.-Atmos., 119, 5671-5699, doi:10.1002/2013JD020914, 2014.

Ziemke, J. R., Douglass, A. R., Oman, L. D., Strahan, S. E., and Duncan, B. N.: Tropospheric ozone variability in the tropics from ENSO to MJO and shorter timescales, Atmos. Chem. Phys., 15, 8037-8049, doi:10.5194/acp-15-8037-2015, 2015. 